\title{
Alkalinity Cycling And Carbonate Chemistry Decoupling in Seagrass Mystify Processes of Acidification Mitigation
}

Cale A. Miller ( $\nabla$ cmill@ucdavis.edu )

University of California Davis

Amanda L. Kelley

University of Alaska Fairbanks

\section{Research Article}

Keywords: seagrass, acidification, alkalinity, carbonate chemistry, phytoremediation

Posted Date: April 16th, 2021

DOI: https://doi.org/10.21203/rs.3.rs-419885/v1

License: (c) (1) This work is licensed under a Creative Commons Attribution 4.0 International License.

Read Full License 
1 Alkalinity cycling and carbonate chemistry decoupling in seagrass mystify processes

2 of acidification mitigation

3

4 Cale A. Miller ${ }^{\mathrm{a}, \mathrm{b}, *}$ and Amanda L. Kelley ${ }^{\mathrm{b}}$

5 a Department of Evolution and Ecology, University of California Davis, Davis, CA, USA, 695616

7 b College of Fisheries and Ocean Sciences, University of Alaska Fairbanks, Fairbanks, 8 AK, USA, 99775

9 *Correspondence: cmill@ucdavis.edu; calemiller620@gmail.com

10 Keywords: seagrass, acidification, alkalinity, carbonate chemistry, phytoremediation

\section{Abstract}

13 The adverse conditions of acidification on sensitive marine organisms has led to the 14 investigation of bioremediation methods as a way to abate local acidification. This 15 phytoremediation, by macrophytes, is expected to reduce the severity of acidification in 16 nearshore habitats on short timescales. Characterizing the efficacy of phytoremediation

17 can be challenging as residence time, tidal mixing, freshwater input, and a limited

18 capacity to fully constrain the carbonate system can lead to erroneous conclusions. Here,

19 we present in situ observations of carbonate chemistry relationships to seagrass habitats

20 by comparing dense (DG), patchy (PG), and no grass (NG) Zostera marina pools in the

21 high intertidal experiencing intermittent flooding. High-frequency measurements of $\mathrm{pH}$,

22 alkalinity (TA), and total- $\mathrm{CO}_{2}$ elucidate extreme diel cyclicity in all parameters. The DG

23 pool displayed frequent decoupling between $\mathrm{pH}$ and aragonite saturation state $\left(\Omega_{\mathrm{arg}}\right)$

24 suggesting $\mathrm{pH}$-based inferences of acidification remediation by seagrass can be

25 misinterpreted as $\mathrm{pH}$ and $\Omega_{\mathrm{arg}}$ can be independent stressors for some bivalves. Estimates

26 show the DG pool had an integrated $\Delta \mathrm{TA}$ of $550 \mu \mathrm{mol} \mathrm{kg}-1$ over a $12 \mathrm{~h}$ period, which is 
$27 \sim 60 \%>$ the PG and NG pools. We conclude habitats with mixed photosynthesizes (i.e.,

28 PG pool) result in less decoupling between $\mathrm{pH}$ and $\Omega_{\mathrm{arg}}$.

\section{Introduction}

31 The myriad biophysical factors that modify estuarine carbonate chemistry often transcend

32 the effects of atmospheric $\mathrm{CO}_{2}$ hydrolysis in seawater (ocean acidification), where the

33 effects of groundwater flux, fluvial inputs, enhanced biological metabolism,

34 eutrophication, upwelling, and tidal pumping interact in complexity resulting in coastal

35 acidification ${ }^{1-4}$. The synthesis of these processes is a long-term $\mathrm{pH}$ variability that is

36 estimated to be $\sim 20 \mathrm{x}$ greater than the open-ocean, where the increasing baseline of

37 dissolved $\mathrm{CO}_{2}$ magnifies the frequency and duration of carbonate chemistry extremes

38 resulting in impeded growth and development of calcifying organisms ${ }^{1,5-9}$. The

39 deleterious socioeconomic implications of acidification has led to policy initiatives aimed

40 at utilizing phytoremediation (i.e., photosynthetic $\mathrm{CO}_{2}$ uptake) by seagrass and kelp to

41 locally mitigate acidification events ${ }^{10-12}$. This assumes that photosynthesis by

42 macrophytes can reduce the dissolved inorganic carbon $\left(\mathrm{TCO}_{2}\right)$ - simultaneously raising

$43 \mathrm{pH}$ - during daylight hours when photosynthetic rates are high relative to heterotrophic

44 respiration in seagrass beds and kelp forests. Initial research on this topic found that

45 daytime reduction of $\mathrm{TCO}_{2}$ by seagrass is capable of increasing $\mathrm{pH}$ on short time scales,

46 however residence time, depth, and enhanced community metabolism in nearshore

47 seagrass habitats were found to dampen mitigation or exacerbate extreme conditions

48 offering only minor, temporary, refuge from acidification ${ }^{9,13-17}$. These equivocal

49 conclusions of carbonate chemistry variability in seagrass habitats may partially explain

50 the contrasting correlations between bivalve growth and proximity to seagrass patches 
$51 \quad 18,19$. Notwithstanding the emerging complexity of phytoremediation, it is clear that

52 further studies are needed to investigate the habitat specificity as it relates to biological

53 communities and the physicochemical oceanographic dynamics of seagrass and kelp

54 ecosystems from an acidification context.

55 To quantify phytoremediation by seagrass the carbonate system needs to be

56 properly constrained as organismal sensitivities to acidification are specific to individual

57 parameters (e.g., $\mathrm{pH}$ and $\mathrm{CaCO}_{3}$ saturation state $\Omega$ ) - acidification is a multi-stressor ${ }^{20,21}$.

58 Complicating matters is the nuance of carbonate chemistry variability in coastal margins

59 where the potential for specific parameters to diverge from co-varying positive

60 correlations (i.e., $\mathrm{pH}$ and $\Omega$ ) is high, a phenomenon referred to as a decoupling of the

61 carbonate system ${ }^{1,22}$. Previous studies have examined seagrass phytoremediation via

62 autonomous $\mathrm{pH}$ and $\mathrm{O}_{2}$ sensors complemented by periodic discrete sampling of $\mathrm{TCO}_{2}$ or

63 TA (total alkalinity) 9,15,17,18,23, however logistics including site accessibility, timing of

64 tidal cycles, and ability to conduct high-frequency sampling often precludes fully

65 constraining the carbonate system; an inherently necessary step in properly identifying

66 occurrences of decoupling and quantifying phytoremediation.

67 To date, most phytoremediation analyses from observations and modelling rely

68 heavily on positive correlations between $\mathrm{pH}$ and seagrass density as a means to identify

69 the potential for acidification mitigation $13,16,17$. Conclusions regarding acidification

70 amelioration are, thus, limited by assumptions of a coupled carbonate system and an

71 opacity to detail the multi-stressor component. In this study, we characterize the

72 carbonate chemistry of adjacent pools in the high intertidal defined as being dense,

73 patchy, or devoid of seagrass (Zostera marina). We measured multiple carbonate 
74 chemistry parameters $\left(\mathrm{pH}, \mathrm{TCO}_{2}\right.$, and $\left.\mathrm{TA}\right)$ in each pool over a 17-d period at high

75 frequency to identify tidal and diurnal patterns of carbonate chemistry change as a

76 function of the presence and abundance of seagrass. Our analysis highlights the

77 frequency of carbonate chemistry decoupling of $\mathrm{pH}$ and $\Omega_{\mathrm{arg}}$ as it relates to seagrass

78 density and TA variability. If this decoupling is common in seagrass beds, then previous

79 estimates of phytoremediation are potentially overestimated due to assumptions about

80 positive correlations among parameters (e.g., $\mathrm{pH}, \Omega_{\mathrm{arg}}$ ) despite the use of a robust TA-

81 salinity relationship in calculating carbonate chemistry variables.

\section{Results}

\section{Timeseries of pool carbonate chemistry}

84 Observations recorded in dense grass (DG: $62 \%$ of pool area), patchy grass (PG: $26 \%$ of

85 pool area), and no grass (NG: $0 \%$ of pool area) pools at the head of Jakolof Bay, AK

86 (Fig. S1), displayed robust hourly changes in $\mathrm{TA}, \mathrm{TCO}_{2}$ and $\mathrm{pH}$ that depicted an

87 increasing dynamic range correlated with residence time from 15 - 24 June (Fig. 1).

88 Immersion time (i.e., period pools were flooded) decreased from 3.85 to $2.60 \mathrm{~h}$ while

89 depth of overlying water at high tide decreased from 1.18 to $0.30 \mathrm{~m}$ during the spring to

90 neap tidal transition increasing the magnitude of carbonate chemistry change (Fig. 1).

91 Over the $17-\mathrm{d}$ period the $\Delta \mathrm{TA}\left(\mu \mathrm{mol} \mathrm{kg}{ }^{-1} \mathrm{~h}^{-1}\right)$ range was greatest in the DG pool with a

92 maximum value $43 \%$ greater than the PG pool, and $26 \%$ greater than the NG pool

93 (Table $\mathrm{S} 1$ ). The $\Delta \mathrm{TCO}_{2}$ maximum rate in the DG pool was double that of its $\Delta \mathrm{TA}$ and

94 only $23 \%$ and $48 \%$ greater than the PG and NG pools, respectively (Table S1).

95 Immediately following each flood cycle when pools were emersed and retained an

96 average depth of $6 \mathrm{~cm}$, the $\mathrm{TA}, \mathrm{TCO}_{2}$, and $\mathrm{pH}_{\mathrm{T}}$ signals were approximately equal to 
97 ocean measurements and similar to normative estuarine systems. This is despite

98 extremely low salinity (Fig. S2) at the surficial layer of the incoming flood tide which

99 lowered ocean TA only at the surface.

Estimated $\mathrm{pH}_{\mathrm{T}}$ calculated from $\mathrm{TCO}_{2}$ and $\mathrm{TA}$ in all pools were robustly different 101 from direct $\mathrm{pH}_{\mathrm{T}}$ measurements (Fig. 1c-e). Measured values were consistently higher

102 where the mean of $\mathrm{pH}_{\mathrm{T}}-\mathrm{pH}_{\mathrm{T}_{-} \text {est }}( \pm \mathrm{SD})$ was $0.38 \pm 0.35$ for $\mathrm{DG}, 0.22 \pm 0.26$ for $\mathrm{PG}$, and $1030.33 \pm 0.23$ for NG pools. The NG pool flooded at a height $0.21 \mathrm{~m}$ higher than DG and 104 PG pools resulting in an extended emersion period and complete evaporation of the pool 105 on 26 June resulting in anomalous measurements after the $24^{\text {th }}$ as robust deviations 106 became present (Fig. S2). The $\mathrm{PG}$ pool had the greatest overall $\mathrm{pH}_{\mathrm{T}}$ range from 7.64 to 1079.25 while the daily extremes were slightly less from 7.64 to 9.14 , and 7.65 to 9.08 for 108 the DG and NG pool, respectively. The daily increase in $\mathrm{pH}_{\mathrm{T}}$ occurred concomitantly 109 with temperature that ranged from $\sim 12.4$ to 26.6 (Fig. S2), which would 110 thermodynamically decrease $\mathrm{pH}_{\mathrm{T}}$ by $\sim 0.225$ units over the TA and salinity values 111 observed due to the positive correlation between temperature and carbonic acid 112 dissociation constants.

\section{Hourly rates of change during emersion}

114 High-frequency sampling of carbonate chemistry and ancillary parameters $\left(\mathrm{O}_{2}\right.$, 115 temperature, salinity, and nutrients) characterize a diel modulation for all pools with 116 increases in TA and $\mathrm{TCO}_{2}$ at night $\left(\mathrm{PAR}<100 \mu \mathrm{mol}\right.$ photons $\left.\mathrm{m}^{-2} \mathrm{~s}^{-1}\right)$ and decreases 117 during the day (Fig. 2a-c). Hourly nighttime increases in $\mathrm{TA}$ and $\mathrm{TCO}_{2}$ for $\mathrm{DG}$ and $\mathrm{PG}$ 118 pools were 42.13 and $48.50\left(\mathrm{R}^{2}=0.99\right.$ and 0.98$)$, and 44.99 and $173.08\left(\mathrm{R}^{2}=0.99\right.$ and 
119 0.92) $\mu \mathrm{mol} \mathrm{kg} \mathrm{kg}^{-1} \mathrm{~h}^{-1}$, respectively. The ratio at which TA and $\mathrm{TCO}_{2}$ increased for the DG

120 (1.07) and PG (1.14) pools was $\sim 1$ whereas the $\mathrm{NG}$ pool had a $\mathrm{TA}: \mathrm{TCO}_{2}$ ratio of 1.84.

121 TA decreased linearly for all pools at a rate $\sim 51.0 \mu \mathrm{mol} \mathrm{kg}^{-1} \mathrm{~h}^{-1}\left(\mathrm{R}^{2}=0.98\right)$ for $\mathrm{DG}$ and

$122 \mathrm{NG}$ pools, and $32.3\left(\mathrm{R}^{2}=0.97\right) \mu \mathrm{mol} \mathrm{kg}{ }^{-1} \mathrm{~h}^{-1}$ for the $\mathrm{PG}$ pool. $\mathrm{TCO}_{2}$ decreased fastest in

123 the $\mathrm{PG}$ pool resulting in higher $\mathrm{pH}_{\mathrm{T}}$ earlier in the day compared to $\mathrm{DG}$ and $\mathrm{NG}$ pools, and

124 a more rapid shift in carbonate chemistry speciation from $\mathrm{HCO}_{3}^{-}$to $\mathrm{CO}_{3}{ }^{2-}$.

125 Supersaturation of $\mathrm{CaCO}_{3}\left(\Omega_{\text {arg }}\right)$ persisted in all pools for the entire emersion period $(\sim 21$

$126 \mathrm{~h}$ ) regardless of PAR levels (Fig. 2d-f). If partitioned by the processes that are known to

127 modify $\mathrm{TCO}_{2}$, it is estimated that the predominate mechanism driving variability was

128 biological respiration and photosynthesis compared to $\mathrm{CaCO}_{3}$ precipitation or dissolution, 129 which outpaced changes in $\left[\mathrm{O}_{2}\right]$ that peaked in late morning.

130 Alkalinity drawdown and associations with seagrass

131 Logistical curve fits to $\Delta \mathrm{TA}$ as a function of emersion time was greatest in the DG pool 132 reaching a maximum of $\sim 550 \mu \mathrm{mol} \mathrm{kg}^{-1} \mathrm{~h}^{-1}(\mathrm{RMSE}=82.3)$ around $10.5 \mathrm{~h}$ compared to 133 the NG $(\mathrm{RMSE}=46.4)$ and $\mathrm{PG}(\mathrm{RMSE}=58.0)$ pools with $\Delta \mathrm{TA}$ maxima of $\sim 300 \mu \mathrm{mol}$ $134 \mathrm{~kg}^{-1} \mathrm{~h}^{-1}$ at $8.5 \mathrm{~h}$ (Fig 3a). At maximum $\Delta \mathrm{TA}$, DG was significantly different than both PG 135 and NG pools represented by nonoverlapping model bounds. The $\Delta$ TA per proportion of 136 seagrass cover over the same emersion period appeared greater in the PG pool relative to 137 the DG pool, however, the large RMSE $(\mathrm{DG}=133.3$ and $\mathrm{PG}=215.5)$ bounds suggests 138 these two pools are undistinguishable (Fig. 3b).

\section{Carbonate chemistry decoupling}


140 Aragonite saturation state and $\left[\mathrm{O}_{2}\right]$ relationships with $\mathrm{pH}_{\mathrm{T}}$ varied by pool for the entire

141 timeseries. A decoupling of a consistent positive correlation between $\mathrm{pH}_{\mathrm{T}}$ and $\Omega_{\arg }$ was

142 observed in the DG and PG pools which displayed $\Omega_{\mathrm{arg}}<1.5$ across a $\mathrm{pH}_{\mathrm{T}}$ range $7.63-$

1439.10 , with a greater proportion of low $\Omega_{\text {arg }}$ values at high $\mathrm{pH}_{\mathrm{T}}$ in the $\mathrm{DG}$ pool relative to 144 the PG pool (Fig. 4). The $\left[\mathrm{O}_{2}\right]$ in the $\mathrm{DG}$ and $\mathrm{PG}$ pools had a gaussian distribution with 145 an RMSE of 51.4 and 55.7, respectively, where $\left[\mathrm{O}_{2}\right]$ peaked at a $\mathrm{pH}_{\mathrm{T}} \sim 8.8$ and then 146 began to decrease. This trend was not present in the NG pool, and a linear relationship 147 was observed in the ocean signal.

\section{Discussion}

150 The extreme diel cyclicity of TA observed in this study is unprecedented for nearshore 151 macrophyte habitats in temperate locations and refutes assumptions of its invariability 152 and strong correlation with salinity, a relationship often used to constrain the carbonate 153 system. The modulation of $\mathrm{pH}_{\mathrm{T}}, \mathrm{TCO}_{2}$, and $\mathrm{TA}$ in each of the pools exceeds those that 154 would be derived based on any two of the carbonate chemistry parameters and 155 exemplifies an uncoupled system likely overlooked by previous studies ${ }^{15-17,23,24}$.

156 Extreme decoupling of the carbonate system was present in the DG bed only where $\mathrm{pH}_{\mathrm{T}}$ 157 ranged from 7.65 to 9.19 while maintaining a salinity $>26$ and $\Omega_{\text {arg }}<1.5-$ a threshold at 158 which acute stress occurs in certain bivalve larva ${ }^{25}$. The two seagrass pools (DG, PG) 159 displayed fundamental differences as it relates to extremes in carbonate chemistry 160 variability, characteristic of previous findings detailing an exacerbation of extremes in 161 seagrass habitats ${ }^{9}$. Despite abundant filamentous macroalgae and observed 
162 microphytobenthos (Fig. S1), the NG pool exhibited a reduced magnitude of variability

163 and maintained a mostly positive correlation between $\mathrm{pH}_{\mathrm{T}}$ and $\Omega_{\text {arg. }}$. The OC signal

164 experienced more modest decoupling, however this was due to the freshwater lens at the

165 surface upon the incoming flood tide. While phytoremediation may appear present during

166 occasions with extremely high $\mathrm{pH}_{\mathrm{T}}$ and $\Omega_{\mathrm{arg}}$, the reduction of $\mathrm{TCO}_{2}$ and bioavailable

167 carbon for calcification remained extremely low, potentially impeding organismal

168 calcification, ${ }^{25-27}$, inducing a result opposite of phytoremediation. While these

169 conclusions are based on in situ timeseries sampling without replication, the consistent

170 behavior and difference between each pool and autocorrelation over the tidal period gives

171 confidence in our conclusions.

172 Model estimates of daytime $\Delta \mathrm{TA}$ as a function of residence time suggest that the

173 mixed autotroph PG pool resulted in a lower integrated TA decrease but a faster rate of

$174 \mathrm{TCO}_{2}$ drawdown shifting the distribution of carbonate chemistry speciation to limited

$175 \mathrm{CO}_{2}$ availability earlier in time (Fig. 5). Based on our results, we hypothesize that higher

176 photosynthetic rates by non-seagrass photosynthesizes (e.g., microphytobenthos) in

177 mixed seagrass communities can raise $\mathrm{pH}$ and drawdown $\mathrm{TCO}_{2}$ faster leading to a more

178 rapid increase in $\mathrm{TA}: \mathrm{TCO}_{2}$ due to the $\mathrm{TCO}_{2}$ uptake physiology by those autotrophs

$17914,28,29$. This is counter to other assertions suggesting greater seagrass density (leaf area

180 index) leads to a greater potential of acidification remediation ${ }^{13}$; it is clear though, that a

181 more rigorous characterization of the carbonate system is needed to address the efficacy

182 of mitigation and potential decoupling of the system.

183 The effects of extreme TA variability relate to changes in the $\mathrm{TA}: \mathrm{TCO}_{2}$ ratio

184 which influence $\mathrm{CaCO}_{3}$ saturation state as well as the sensitivity of carbonate chemistry 
185 parameters (e.g., $\mathrm{pH}$ and $\left.\mathrm{PCO}_{2}\right)^{30}$. The $\mathrm{TA}: \mathrm{TCO}_{2}$ ratio ranged from 1.05 to 1.80 with

186 highs correlated to longer residence times during neap tidal periods that affected the

187 duration of immersion and emersion. Studies that have previously recorded such changes

188 in TA identify benthic flux or $\mathrm{CaCO}_{3}$ dissolution as the driver of diel variability, however

189 the attributes of the sediment in those habitats were permeable, medium sand or coarse,

190 and rich in $\mathrm{CaCO}_{3}$ - conducive conditions for enhanced diffusive and advective efflux

191 from porewater ${ }^{31-33}$. While decreases in TA have been found as a result of calcification

192 by epibionts or by seagrass leaves themselves, those scenarios occurred in tropical

193 environments with waters extremely high in $\mathrm{CaCO}_{3}$, or in temperate nearshore waters

194 where riverine inputs carried high [TCO2] and [TA] where $\Omega_{\arg }$ was found to be $>10$ in

195 the submerged aquatic habitats; however, neither reported diel cycling of TA or found the

196 unique TA: $\mathrm{TCO}_{2}$ ratios observed here ${ }^{34,35}$. In this study, the sediment for all pools was

197 muddy and interspersed with gravel. Porewater profiles at 1, 2, and $3 \mathrm{~cm}$ depths depicted

$198\left[\mathrm{TCO}_{2}\right]>\left[\mathrm{TA}_{\mathrm{Carb}}\right]$ and were consistently higher than the concentrations in the overlying

199 water (Fig. S3). Given this orientation, efflux of TA and $\mathrm{TCO}_{2}$ from porewater should be

200 persistent, particularly as the concentration gradient would increase during the day as TA

201 and $\mathrm{TCO}_{2}$ decreased in the pools.

202 If we assume the solute exchange between porewater and overlying water was the 203 mechanism for observed diel TA variability, we can estimate an integrated benthic flux at 204 night in the DG pool of $4.4 \mathrm{mmol} \mathrm{m}^{-2}(\sim 6 \mathrm{~h})$ and $\sim 10 \mathrm{mmol} \mathrm{m}^{-2}(\sim 12 \mathrm{~h})$ during the day, 205 with daytime rates for the PG and NG pools slightly lower at $\sim 5.5 \mathrm{mmol} \mathrm{m}^{-2}$. These rate 206 estimates are similar to those reported in tropical environments where TA flux occurs 207 concomitantly with dissolution in permeable sediments ${ }^{31}$, however, there was no 
208 evidence of high $\mathrm{CaCO}_{3}$ in the muddy sediments at this site, nor calcifying epiphytes-

209 epiphytic growth overall was surprisingly minimal. The linear changes in TA over the 21

$210 \mathrm{~h}$ period would assume a diffusive flux with a likely stagnant boundary layer because

211 advective processes that can enhance flux rates were limited to bio-irrigation and-

212 turbation - which visually appeared minimal — due to lack of other forces (e.g., wave,

213 current, tide). The characteristics of TA variability were expressed as linear rates of

214 change during the day and at night, whereas $\mathrm{TCO}_{2}$ changes were nonlinear during the day

215 and linear at night. At night TA and $\mathrm{TCO}_{2}$ increased $\sim 1: 1$ in the $\mathrm{DG}$ and $\mathrm{PG}$ pools,

216 which exemplified a possible scenario of $\mathrm{CaCO}_{3}$ dissolution (2:1 change) coupled with

217 respiration that would change $\mathrm{TA}: \mathrm{TCO}_{2} 0: 1$. If plausible, this would have to occur in

218 superstrated waters $\left(\Omega_{\text {arg }}\right.$ was $\left.>1\right)$ where the $\Delta \mathrm{O}_{2}$ roughly matches the estimated-

219 respiration only $-\Delta \mathrm{TCO}_{2}$. This was not the case, however, as the $\Delta \mathrm{TCO}_{2}$ was $<\Delta \mathrm{O}_{2}$ after

$2203 \mathrm{~h}$ (ratio of 0.55 and 0.44 , respectively) and mixed after $6 \mathrm{~h}$ with a ratio of 0.75 and 2.0

221 in the DG and PG pools, respectively. Denitrification-nitrification processes could

222 account for this excess $\mathrm{O}_{2}$ lowering the community respiration quotient in seagrass

223 communities ${ }^{36}$, however, the $\left[\mathrm{NO}_{\mathrm{x}}\right]$ and $\left[\mathrm{NH}_{4}{ }^{+}\right]$were inconclusive correlatives for which

224 to draw any such conclusions (Table S1). In addition, when $\mathrm{PO}_{4}^{3-}$ and $\mathrm{SiO}_{2}$ were

225 measured, correlations with TA were not found. These speculations for TA variability of

226 course assume $\Delta \mathrm{TCO}_{2}$ could be partitioned by precipitation/dissolution, of which there is

227 no strong evidence. This further complicates the identification of processes responsible

228 for TA variability and, thus, provokes the speculation of non-dissolution mechanisms.

229 The modulation of TA and $\mathrm{TCO}_{2}$ at $1: 1$ suggest $\mathrm{HCO}_{3}{ }^{-}$as a potential driver as this

230 would affect both parameters. If $\Delta \mathrm{TCO}_{2}$ and $\Delta \mathrm{TA}$ are a function of proportion seagrass 
231 cover, then TA and $\mathrm{TCO}_{2}$ fluctuate linearly in the DG pool, supporting $\mathrm{HCO}_{3}{ }^{-}$as the

232 modulator (Fig. S4). Specific seagrass species including Z. marina and other macrophytes

233 are known to utilize $\mathrm{HCO}_{3}{ }^{-}$as a carbon source ${ }^{37-39}$. Evidence suggests the active uptake

234 of $\mathrm{HCO}_{3}{ }^{-}$occurs via $\mathrm{H}^{+}$symport in $P$. oceanica, where electroneutrality is likely

235 preserved by a $\mathrm{Cl}^{-}$or $\mathrm{NO}_{3}{ }^{-}$efflux and $\mathrm{Na}^{+} / \mathrm{H}^{+}$antiport ${ }^{40,41}$. The accumulation of $\mathrm{HCO}_{3}{ }^{-}$in

236 P. oceanica aids in the establishment of a robust electronegative potential in the leaves,

237 which is also a phenomenon present in $\mathrm{Z}$. marina ${ }^{41}$. The accumulation of $\mathrm{HCO}_{3}{ }^{-}$within

238 the cell wall may occur at a faster rate than the dehydration to $\mathrm{CO}_{2}$ in the cytoplast

239 catalyzed by carbonic anhydrase, which could lead to efflux of undehydrated $\mathrm{HCO}_{3}{ }^{-}$at

240 night when light energy is limiting. This could also explain the disparity between $\mathrm{O}_{2}$

241 generation and $\mathrm{TCO}_{2}$ drawdown during the day as hysteresis can occur on the timescale

242 of hours ${ }^{42}$, which could be further modified by photorespiration ${ }^{43}$. The evidence here,

243 along with the suggested mechanisms by which electroneutrality is preserved when

$244 \mathrm{HCO}_{3}^{-}$uptake occurs could explain the decrease in TA observed in these pools when

$245 \mathrm{TCO}_{2}$ is limiting. Photosynthesis, however, is not presumed to affect TA even if $\mathrm{HCO}_{3}^{-}$is

246 utilized because it is expected that uptake would be compensated with $\mathrm{H}^{+}$or $\mathrm{OH}^{-}$

247 exchange ${ }^{44}$. More evidence is needed though to determine if this is the case in higher

248 order photosynthesizes because research shows electroneutrality preservation by $\mathrm{OH}^{-}$and

$249 \mathrm{H}^{+}$may be replaced by $\mathrm{NA}^{+}, \mathrm{Cl}^{-}$and $\mathrm{NO}_{3}{ }^{-}$in some seagrasses ${ }^{39,40,45}$. Anomalous to this

250 conclusion would be the observed TA variability in the NG pool. The Ulva spp., which

251 was observed in the $\mathrm{NG}$ pool, however, can also take up $\mathrm{HCO}_{3}{ }^{-}$via ion exchange,

252 potentially with $\mathrm{OH}^{-}$or $\mathrm{Cl}^{-38,46}$. While further investigation is needed to identify the

253 mechanism of TA variability in these pools, similarly low TA values and cycling have 
254 been recorded in enclosed bays with long residence times and abundant seagrass, and 255 even speculation of $\mathrm{HCO}_{3}{ }^{-}$as a cause ${ }^{33,43,47}$. These incidences of low TA and its diel 256 cycling, however, were not assessed from a phytoremediation standpoint, thus the 257 implications hitherto remained unappreciated.

258 The pools in this study are representative microcosms of larger systems, 259 replicating carbonate chemistry variability in seagrass habitats on a magnified scale. 260 Perched estuaries, lagoons, and enclosed bays with long residence times have recoded 261 extremely high $\mathrm{pH}$ values similar to those found in this study, including instances of 262 reduced TA: correlated to the proximity of oceanic influence ${ }^{43,47,48}$. In these systems, 263 biological metabolism and evaporation become the dominate mechanisms that modify $\mathrm{pH}$ $2645,48,49$. It would be remiss to note, however, that the thermodynamic controls on carbonate 265 chemistry also become enhanced at long residence times as was seen in this study. 266 Observed temperature fluctuations ranged from $\sim 12.5-26.5^{\circ} \mathrm{C}$ increasing the carbonic 267 acid dissociation constants resulting in an estimated $\mathrm{pH}$ drop of $\sim 0.21$ units across the 268 recorded $\mathrm{pH}$ and TA range (Fig. S2); however, this was superseded by photosynthetic 269 modification of $\mathrm{pH}$. Evaporation appeared to have little effect on the DG and PG pools as 270 salinity remained fairly constant even at extreme temperatures (Fig. S2). Noticeable was 271 the complete evaporation of the NG pool and the rapid salinity increase, suggesting that

272 small variations in the volume of tidal immersion (i.e., depth of overlying water) can

273 modulate the degree to which estuary carbonate chemistry is affected by the slope of the 274 tidal region.

275 Findings here show unequivocal, frequent, decoupling of carbonate chemistry, 276 and without over constraining the system, previous conclusions regarding $\mathrm{pH}$ and $\mathrm{CO}_{2}$ 
277 variability within seagrass habitats from a perspective of phytoremediation can be

278 overestimated. This can occur despite a robust TA-salinity relationship or because of a

279 mischaracterization of TA variability if results are derived from discrete samples based

280 on specific sampling times corresponding to tidal period and proximity to macrophyte

281 habitat (above or in canopy), and coupled with pH only monitoring. In accordance with

282 previous studies, findings here show that long residence times and spatial variability

283 along with tidal and current mixing are strong drivers for determining carbonate

284 chemistry variability in seagrass ${ }^{13,15}$, however, we show that decoupling of the carbonate

285 system in dense seagrass occurs independent of low salinity and is likely related to

286 extreme TA variability caused by a hysteresis of how $\mathrm{HCO}_{3}{ }^{-}$cycles within the medium in

287 a carbon limited system.

289 Materials and Methods

290 Three shallow, adjacent pools with varying depth on the edges, within $50 \mathrm{~m}$ of one

291 another were selected as sample sites and characterized as dense grass (DG), patchy grass

292 (PG), and no grass (NG) with ellipse areas $~ 330.9,180.0,339.9 \mathrm{~m}^{2}$ with average center

293 depths $5.1,6.2$, and $7.1 \mathrm{~cm}$, respectively, in the high intertidal of Jakolof Bay, AK: $59^{\circ}$

294 26' 54.09" N, $151^{\circ} 29^{\prime}$ 49.96" W (Fig. S1). TA, $\mathrm{TCO}_{2}, \mathrm{pH}_{\mathrm{T}}, \mathrm{O}_{2}$, and salinity samples were

295 collected toward the center of pools at maximum depth at intervals $\sim 16$ and $8 \mathrm{~h}$ for $17 \mathrm{~d}$,

296 with high-frequency sampling occurring every $3 \mathrm{~h}$ on 24 June 22:30 AKT during a $21 \mathrm{~h}$

297 emersion period. $\mathrm{TA}, \mathrm{pH}_{\mathrm{T}}$ and $\mathrm{O}_{2}$ samples were collected in two separate $150 \mathrm{~mL}$

298 borosilicate bottles (one with optical dot), while measurements for $\mathrm{TCO}_{2}$ were collected

299 in a $5 \mathrm{~mL}$ centrifugal tube and poisoned for preservation with $10 \mu \mathrm{L}$ of saturated $\mathrm{HgCl}_{2}$. 
300 Temperature measurements were made in situ with an Omega HH81A digital

301 thermometer, while $\mathrm{TA}, \mathrm{pH}_{\mathrm{T}}$, salinity, and $\mathrm{O}_{2}$, were measured at Kasitsna Bay Laboratory

302 within 30 min of collection. TA was measured using an Apollo SciTech AS-ALK 2 with

303 duplicate titrations performed haphazardly throughout the entire sample collection, and

304 CRMs (certified reference material: batch \#181) measured before and after each machine

305 calibrated run. $\mathrm{pH}_{\mathrm{T}}$ was measured potentiometrically with a Thermo Scientific ROSS

306 Ultra electrode calibrated at total scale with Tris buffer and corrected with an offset that

307 was derived from a regression of 25 samples between potentiometric and

308 spectrophotometric measurements using a Shimadzu UV-1900: this offset was 0.019

309 units (Fig. S5). $\mathrm{O}_{2}$ measurements were performed with a PreSens Fibox 4 after each

310 sample was collected and immediately stored in a dark box in the field until measurement

$311 \sim 30$ min later. Salinity was measured with a YSI 3100 conductivity meter. All $\mathrm{TCO}_{2}$

312 samples were run at Shannon Point Marine Center, WA, on an Apollo SciTech AS-C3

313 along with several CRMs (batch \#179) interspersed after calibration. The uncertainty for

314 measured TA $(7.58 \pm 8.78 \mathrm{SD})$ and $\mathrm{TCO}_{2}(6.77 \pm 6.32 \mathrm{SD})$ was the average difference

315 between known CRM and measured CRM across all samples.

$316 \quad$ Estimated $\mathrm{pH}_{\mathrm{T}}$ and $\Omega_{\text {arg }}$ were calculated using CO2SYS (Matlab V1.1) with

317 inputs $\mathrm{TA}$ and $\mathrm{TCO}_{2}$ using the carbonic acid dissociation constants from Lueker et al. ${ }^{50}$,

318 the bisulfate dissociation constant of Dickson et al. ${ }^{51}$, and the boron constant from

319 Uppström ${ }^{52}$. Assuming the $\Delta \mathrm{TCO}_{2}$ over the $21 \mathrm{~h}$ sampling period was a response to

320 photosynthesis/respiration and $\mathrm{CaCO}_{3}$ precipitation/dissolution, estimates of partitioned

$321 \Delta \mathrm{TCO}_{2}$ were calculated using the absolute hourly rate of change for $\mathrm{TCO}_{2}$ and $\mathrm{TA}$ during

322 each time point. Where $\Delta \mathrm{TA} * 0.5$ (based on the alkalinity anomaly) was equal to the 
$323 \Delta \mathrm{TCO}_{2}$ as a result of precipitation or dissolution, and the remainder of $\triangle \mathrm{TCO} 2-$

$324 \Delta \mathrm{TA}^{*} 0.5$ was a due to biological metabolism. Proportion of cover was calculated by

325 measuring the length and width of each pool and then using photographed images to

326 define the proportion of pool area covered by Z. marina present as a ratio of pool size

327 using ImageJ (v. 1.53a).

328 Logistic curves were fit to each pool correlating $\Delta \mathrm{TA}$ with emersion time when

329 samples were collected immediately after and before flood tide. This ended up being 12

330 time points for DG and PG pools and 10 for the NG pool (pool evaporated at day 15)

331 during the change in tidal cycle from spring to neap. A conceptual model of carbonate

332 chemistry dynamics for the DG and PG pools was determined by using the estimated

333 values of $\triangle \mathrm{TA}$ across the entire time series (described above) and the changes in

334 carbonate chemistry speciation derived from the high frequency $21 \mathrm{~h}$ sampling period.

335 Since the $\Delta \mathrm{TA}$ during the $21 \mathrm{~h}$ sampling period was integrated into the entire timeseries

336 estimates, the carbonate speciation changes are representative of the expected dynamics

337 that would be visible at other time points.

338 Porewater collectors were assembled using Super Speedfit polypropylene 6.35

$339 \mathrm{~mm}$ press-connect fittings. T-shaped connectors were fit with two, $\sim 3.8 \mathrm{~cm}$ length pieces

340 of food grade plastic tubing, with open ends sealed with thermoplastic hot melt adhesive.

341 Two sides of each piece of tubing were punctured five times with a 16-gauge needle,

342 wrapped with a 0.45 micron PES membrane filter and adhered with thermoplastic

343 adhesive to keep out sediment. Three collectors for each pool were buried at 1, 2, and 3

344 cm depths (Fig. S1), $36 \mathrm{~h}$ and 3 tidal cycles before the first samples were collected. The 
345 top of each T-connector - which protruded above the sediment — was sealed with a Super 346 Speedfit polypropylene plug.

Prior to collection, $5 \mathrm{~mL}$ centrifugal tubes were placed in a glove bag purged of

$348 \mathrm{O}_{2}$ and filled with $\mathrm{N}_{2}$. Vials sat in the glove bag with caps off for 1-2 $\mathrm{h}$ while being filled 349 with $\mathrm{N}_{2}$ and shaken haphazardly. The caps of each vial had a $6.35 \mathrm{~mm}$ hole drilled in the 350 top and then covered with electrical tape. Caps were secured from inside glove bag and 351 vials then stored and transported in a plastic bag. A $10 \mathrm{~mL}$ serological pipette fitted with 352 a $6.35 \mathrm{~mm}$ piece of rigid tubing was fit into the top of each press-connect securing a tight 353 connection and porewater slowly extracted. The first $2 \mathrm{~mL}$ of water was discarded and 4 $354-5 \mathrm{~mL}$ transferred to the vial by removing tape temporarily and injecting the collected 355 porewater into the vial. Samples were measured immediate for $\mathrm{pH}_{\mathrm{T}}$ using a Thermo 356 Scientific ROSS Ultra electrode calibrated with Tris buffer and reported on the total 357 scale. A 0.019 correction factor derived from a 25-sample regression between 358 potentiometric and spectrophotometric measurements using a Shimadzu UV-1900 was 359 applied. After $\mathrm{pH}$ measurement, samples were poisoned with $10 \mu \mathrm{L}$ of saturated $\mathrm{HgCL}_{2}$ 360 and capped with a new screw top until $\mathrm{TCO}_{2}$ was measured at Shannon Point Marine 361 Center, Anacortes, WA, on an Apollo SciTech AS-C3. Samples were collected every 3 d. 362 Nutrient $\mathrm{NO}_{x}, \mathrm{NH}^{4+}, \mathrm{PO}_{4}{ }^{3-}$, and $\mathrm{SiO}_{4}$ samples were collected in each pool every 3 $363 \mathrm{~h}$ during the $21 \mathrm{~h}$ sampling period starting 24 June 2019. Water samples were collected 364 with a $60 \mathrm{~mL}$ syringe and filtered through a GFF with a particle retention rate of $1.2 \mu \mathrm{m}$ 365 into a $20 \mathrm{~mL}$ scintillation vial. Samples were frozen at $-4{ }^{\circ} \mathrm{C}$ within $30 \mathrm{~min}$ of collection 366 until analysis. Samples were processed on a SmartChem multi-element analyzer at 367 Oregon State University. 
376 1. Waldbusser, G. G. \& Salisbury, J. E. Ocean Acidification in the Coastal Zone from 377 an Organism's Perspective: Multiple System Parameters, Frequency Domains, and 378 Habitats. Annu. Rev. Mar. Sci. 6, 221-247 (2014).

379 2. Duarte, C. M. et al. Is Ocean Acidification an Open-Ocean Syndrome?

380 Understanding Anthropogenic Impacts on Seawater pH. Estuaries Coasts 36, 221$381 \quad 236(2013)$

382 3. Johnson, Z. I. et al. Dramatic Variability of the Carbonate System at a Temperate 383 Coastal Ocean Site (Beaufort, North Carolina, USA) Is Regulated by Physical and 384 Biogeochemical Processes on Multiple Timescales. PLOS ONE 8, e85117 (2013).

385 4. Baumann, H. \& Smith, E. M. Quantifying Metabolically Driven pH and Oxygen 386 Fluctuations in US Nearshore Habitats at Diel to Interannual Time Scales. Estuaries $387 \quad$ Coasts 41, 1102-1117 (2018).

388 5. Carstensen, J. \& Duarte, C. M. Drivers of pH Variability in Coastal Ecosystems. 389 Environ. Sci. Technol. 53, 4020-4029 (2019).

390 6. Clark, H. R. \& Gobler, C. J. Diurnal fluctuations in $\mathrm{CO}_{2}$ and dissolved oxygen 391 concentrations do not provide a refuge from hypoxia and acidification for early-life392 stage bivalves. Mar. Ecol. Prog. Ser. 558, 1-14 (2016). 
393 7. Mangan, S., Urbina, M. A., Findlay, H. S., Wilson, R. W. \& Lewis, C. Fluctuating seawater $\mathrm{pH} / p \mathrm{CO}_{2}$ regimes are more energetically expensive than static $\mathrm{pH} / \mathrm{pCO} 2$ levels in the mussel Mytilus edulis. Proc. R. Soc. B Biol. Sci. 284, 20171642 (2017).

396 8. Hauri, C., Gruber, N., McDonnell, A. M. P. \& Vogt, M. The intensity, duration, and 397 severity of low aragonite saturation state events on the California continental shelf. 398 Geophys. Res. Lett. 40, 3424-3428 (2013).

9. Pacella, S. R., Brown, C. A., Waldbusser, G. G., Labiosa, R. G. \& Hales, B. Seagrass 400 habitat metabolism increases short-term extremes and long-term offset of $\mathrm{CO}_{2}$ under 401 future ocean acidification. Proc. Natl. Acad. Sci. U. S. A. 115, 3870-3875 (2018).

10. Washington State Blue Ribbon panel on Ocean Acidification. Scientific summary of ocean acidification in Washington State marine waters: Washington shellfish initiative Blue Ribbon panel on ocean acidification. (U. S. Dept. of Commerce, $405 \quad$ National Oceanic Atmospheric Administration, 2012).

406 11. Nielsen, K. et al. Seagrass and Kelp as an Ocean Acidification Management Tool in 407 California - Ocean Science Trust. http://www.oceansciencetrust.org/projects/sav/ $408 \quad$ (2018).

409 12. Ekstrom, J. A. et al. Vulnerability and adaptation of US shellfisheries to ocean $410 \quad$ acidification. Nat. Clim. Change 5, 207-214 (2015).

411 13. Koweek, D. A. et al. Expected limits on the ocean acidification buffering potential of 412 a temperate seagrass meadow. Ecol. Appl. 28, 1694-1714 (2018).

413 14. Miller, C. A., Yang, S. \& Love, B. A. Moderate Increase in $\mathrm{TCO}_{2}$ Enhances 414 Photosynthesis of Seagrass Zostera japonica, but Not Zostera marina: Implications 415 for Acidification Mitigation. Front. Mar. Sci. 4, (2017). 
416 15. Cyronak, T. et al. Short-Term Spatial and Temporal Carbonate Chemistry Variability

417 in Two Contrasting Seagrass Meadows: Implications for $\mathrm{pH}$ Buffering Capacities.

$418 \quad$ Estuaries Coasts 41, 1282-1296 (2018).

419 16. Unsworth, R. K. F., Collier, C. J., Henderson, G. M. \& McKenzie, L. J. Tropical

420 seagrass meadows modify seawater carbon chemistry: implications for coral reefs

421 impacted by ocean acidification. Environ. Res. Lett. 7, 024026 (2012).

422 17. Hendriks, I. E. et al. Photosynthetic activity buffers ocean acidification in seagrass

423 meadows. Biogeosciences 11, 333-346 (2014).

424 18. Greiner, C. M., Klinger, T., Ruesink, J. L., Barber, J. S. \& Horwith, M. Habitat

425 effects of macrophytes and shell on carbonate chemistry and juvenile clam

426 recruitment, survival, and growth. J. Exp. Mar. Biol. Ecol. 509, 8-15 (2018).

427 19. Groner, M. L. et al. Oysters and eelgrass: potential partners in a high $p \mathrm{CO}_{2}$ ocean.

$428 \quad$ Ecology 99, 1802-1814 (2018).

429 20. Waldbusser, G. G. et al. Ocean Acidification Has Multiple Modes of Action on

$430 \quad$ Bivalve Larvae. PLOS ONE 10, e0128376 (2015).

431 21. Hurd, C. L. et al. Ocean acidification as a multiple driver: how interactions between

432 changing seawater carbonate parameters affect marine life. Mar. Freshw. Res. 71,

$433 \quad 263-274(2020)$.

434 22. Hales, B., Suhrbier, A., Waldbusser, G. G., Feely, R. A. \& Newton, J. A. The

435 Carbonate Chemistry of the "Fattening Line," Willapa Bay, 2011-2014. Estuaries

$436 \quad$ Coasts 1-14 (2016) doi:10.1007/s12237-016-0136-7.

437 23. Ricart, A. M. et al. Coast-wide evidence of low $\mathrm{pH}$ amelioration by seagrass

438 ecosystems. Glob. Change Biol. n/a,. 
24. Buapet, P., Gullström, M. \& Björk, M. Photosynthetic activity of seagrasses and macroalgae in temperate shallow waters can alter seawater $\mathrm{pH}$ and total inorganic carbon content at the scale of a coastal embayment. Mar. Freshw. Res. (2013).

25. Waldbusser, G. G. et al. Saturation-state sensitivity of marine bivalve larvae to ocean acidification. Nat. Clim. Change 5, 273-280 (2015).

26. Comeau, S., Carpenter, R. C. \& Edmunds, P. J. Coral reef calcifiers buffer their response to ocean acidification using both bicarbonate and carbonate. Proc. R. Soc. B-Biol. Sci. 280, 20122374 (2013).

27. Jury, C. P., Whitehead, R. F. \& Szmant, A. M. Effects of variations in carbonate chemistry on the calcification rates of Madracis auretenra (= Madracis mirabilis sensu Wells, 1973): bicarbonate concentrations best predict calcification rates. Glob. Change Biol. 16, 1632-1644 (2010).

28. Raven, J. A., Giordano, M., Beardall, J. \& Maberly, S. C. Algal evolution in relation to atmospheric $\mathrm{CO}_{2}$ : carboxylases, carbon-concentrating mechanisms and carbon oxidation cycles. Philos. Trans. R. Soc. B Biol. Sci. 367, 493-507 (2012).

29. Vieira, S., Cartaxana, P., Máguas, C. \& Marques da Silva, J. Photosynthesis in estuarine intertidal microphytobenthos is limited by inorganic carbon availability. Photosynth. Res. 128, 85-92 (2016).

30. Egleston, E. S., Sabine, C. L. \& Morel, F. M. M. Revelle revisited: Buffer factors that quantify the response of ocean chemistry to changes in DIC and alkalinity. Glob. Biogeochem. Cycles 24, GB1002 (2010). 
31. Cyronak, T., Santos, I. R., McMahon, A. \& Eyre, B. D. Carbon cycling hysteresis in permeable carbonate sands over a diel cycle: Implications for ocean acidification. Limnol. Oceanogr. 58, 131-143 (2013).

32. Burdige, D. J. \& Zimmerman, R. C. Impact of sea grass density on carbonate dissolution in Bahamian sediments. Limnol. Oceanogr. 47, 1751-1763 (2002).

33. Chou, W.-C. et al. A Unique Diel Pattern in Carbonate Chemistry in the Seagrass Meadows of Dongsha 1 Island: implications for ocean acidification buffering. Geophys. Res. Lett. (In review).

34. Su, J. et al. Chesapeake Bay acidification buffered by spatially decoupled carbonate mineral cycling. Nat. Geosci. 13, 441-447 (2020).

35. Enríquez, S. \& Schubert, N. Direct contribution of the seagrass Thalassia testudinum to lime mud production. Nat. Commun. 5, 3835 (2014).

36. Martin, S. et al. Comparison of Zostera marina and maerl community metabolism. Aquat. Bot. 83, 161-174 (2005).

37. Invers, O., Zimmerman, R. C., Alberte, R. S., Pérez, M. \& Romero, J. Inorganic carbon sources for seagrass photosynthesis: an experimental evaluation of bicarbonate use in species inhabiting temperate waters. J. Exp. Mar. Biol. Ecol. 265, 203-217 (2001).

38. Sand-Jensen, K. \& Gordon, D. M. Differential ability of marine and freshwater macrophytes to utilize $\mathrm{HCO}_{3}{ }^{-}$and $\mathrm{CO}_{2}$. Mar. Biol. 80, 247-253 (1984).

39. Larkum, A. W. D., Davey, P. A., Kuo, J., Ralph, P. J. \& Raven, J. A. Carbonconcentrating mechanisms in seagrasses. J. Exp. Bot. 68, 3773-3784 (2017). 
40. Rubio, L. et al. Direct uptake of $\mathrm{HCO}_{3}{ }^{-}$in the marine angiosperm Posidonia oceanica (L.) Delile driven by a plasma membrane $\mathrm{H}^{+}$economy. Plant Cell Environ. 40, 2820$2830(2017)$

41. Fernández, J. A., García-Sánchez, M. J. \& Felle, H. H. Physiological evidence for a proton pump and sodium exclusion mechanisms at the plasma membrane of the marine angiosperm Zostera marina L. J. Exp. Bot. 50, 1763-1768 (1999).

42. Berg, P. et al. Dynamics of benthic metabolism, $\mathrm{O}_{2}$, and $p \mathrm{CO}_{2}$ in a temperate seagrass meadow. Limnol. Oceanogr. 64, 2586-2604 (2019).

43. Buapet, P., Rasmusson, L. M., Gullstrom, M. \& Bjork, M. Photorespiration and Carbon Limitation Determine Productivity in Temperate Seagrasses. Plos One 8, e83804 (2013)

44. Wolf-Gladrow, D. A., Zeebe, R. E., Klaas, C., Körtzinger, A. \& Dickson, A. G. Total alkalinity: The explicit conservative expression and its application to biogeochemical processes. Mar. Chem. 106, 287-300 (2007).

45. García-Sánchez, M. J., Jaime, M. P., Ramos, A., Sanders, D. \& Fernández, J. Sodium-Dependent Nitrate Transport at the Plasma Membrane of Leaf Cells of the Marine Higher Plant Zostera marina L. Plant Physiol. 122, 879-886 (2000).

46. Drechsler, Z. \& Beer, S. Utilization of Inorganic Carbon by Ulva lactuca. Plant Physiol. 97, 1439-1444 (1991).

47. Ribas-Ribas, M. et al. Effects of upwelling, tides and biological processes on the inorganic carbon system of a coastal lagoon in Baja California. Estuar. Coast. Shelf Sci. 95, 367-376 (2011). 
48. Omarjee, A., Taljaard, S., Weerts, S. P. \& Adams, J. B. The influence of mouth status on $\mathrm{pH}$ variability in small temporarily closed estuaries. Estuar. Coast. Shelf Sci. 246, $107043(2020)$.

49. McCutcheon, M. R., Staryk, C. J. \& Hu, X. Characteristics of the Carbonate System in a Semiarid Estuary that Experiences Summertime Hypoxia. Estuaries Coasts (2019) doi:10.1007/s12237-019-00588-0.

50. Lueker, T. J., Dickson, A. G. \& Keeling, C. D. Ocean $p \mathrm{CO}_{2}$ calculated from dissolved inorganic carbon, alkalinity, and equations for $\mathrm{K}_{1}$ and $\mathrm{K}_{2}$ : validation based on laboratory measurements of $\mathrm{CO} 2$ in gas and seawater at equilibrium. Mar. Chem. 70, $105-119(2000)$.

51. Dickson, A. Thermodynamics of the Dissociation of Boric-Acid in Synthetic Seawater from 273.15-K to 318.15-K. Deep-Sea Res. Part-Oceanogr. Res. Pap. 37, 755-766 (1990).

52. Uppström, L. R. The boron/chlorinity ratio of deep-sea water from the Pacific Ocean. Deep Sea Res. Oceanogr. Abstr. 21, 161-162 (1974).

\section{Acknowledgments}

We would like to thank Edwin (Ted) Grosholz and J. Jay Stachowicz for providing feedback and comments to previous iterations of this manuscript. We would also like to thank Brooke Love and Gene McKeen at Shannon Point Marine Center and George Waldbusser at Oregon State University for use of analytical instrumentations to process samples. 
535

536

537

538

539

540

541

542

543

544

545

546

547

548

549

550

551

552

553

554

555

556

557

558

559

560

561

562

563

564

565

566

567

568

569

570

571

572

573

574

575

576

577

578

Author Contributions: CAM and ALK designed the study. CAM performed all sample collection, processing, and data analysis. CAM led the writing with editing and contributions from ALK.

Additional Information: The authors report no conflicts of interest. 
a.

b.

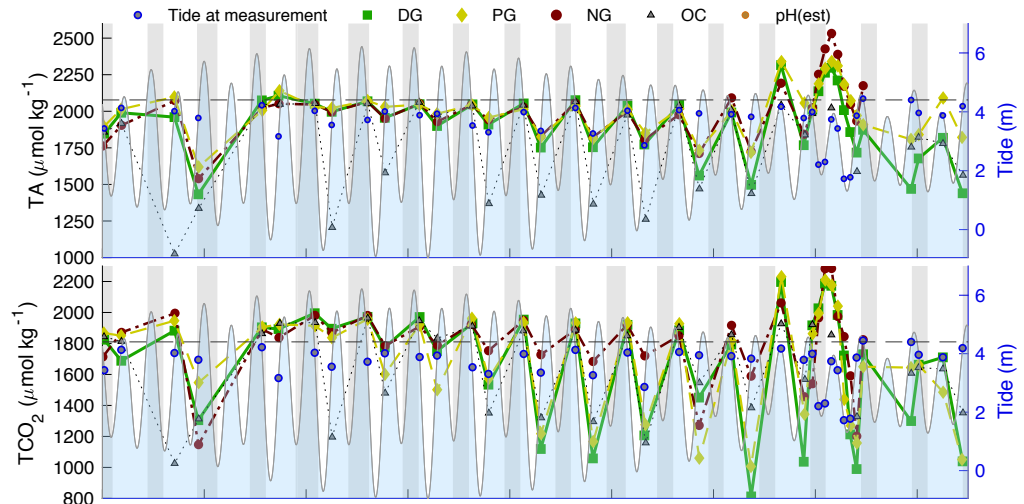

c.

d.
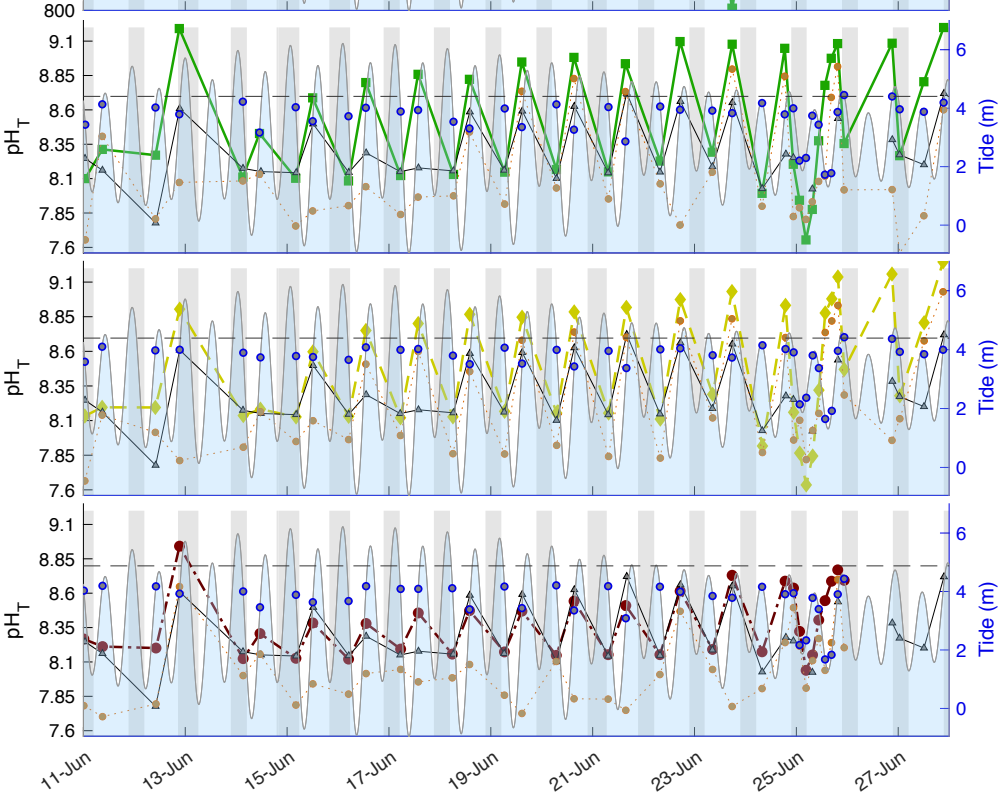

Figure 1. Timeseries of measured $\mathrm{TA}(\mathbf{a}), \mathrm{TCO}_{2}(\mathbf{b}), \mathrm{pH}_{\mathrm{T}}$ and estimated $\mathrm{pH}_{\mathrm{T}}(\mathbf{c}-\mathbf{e})$ in dense grass (DG), patchy grass (PG), no grass (NG), and ocean (OC). Shaded blue region is predicted tide and shaded grey is night when PAR $<100 \mu \mathrm{mol}$ photons $\mathrm{m}^{-2} \mathrm{~s}^{-1}$. Dashed line indicates tidal height when pools become immersed and tidal height at when samples were taken (blue dots). Three-hour sampling occurred for a period of $24 \mathrm{~h}$ starting 24 
a.

b.
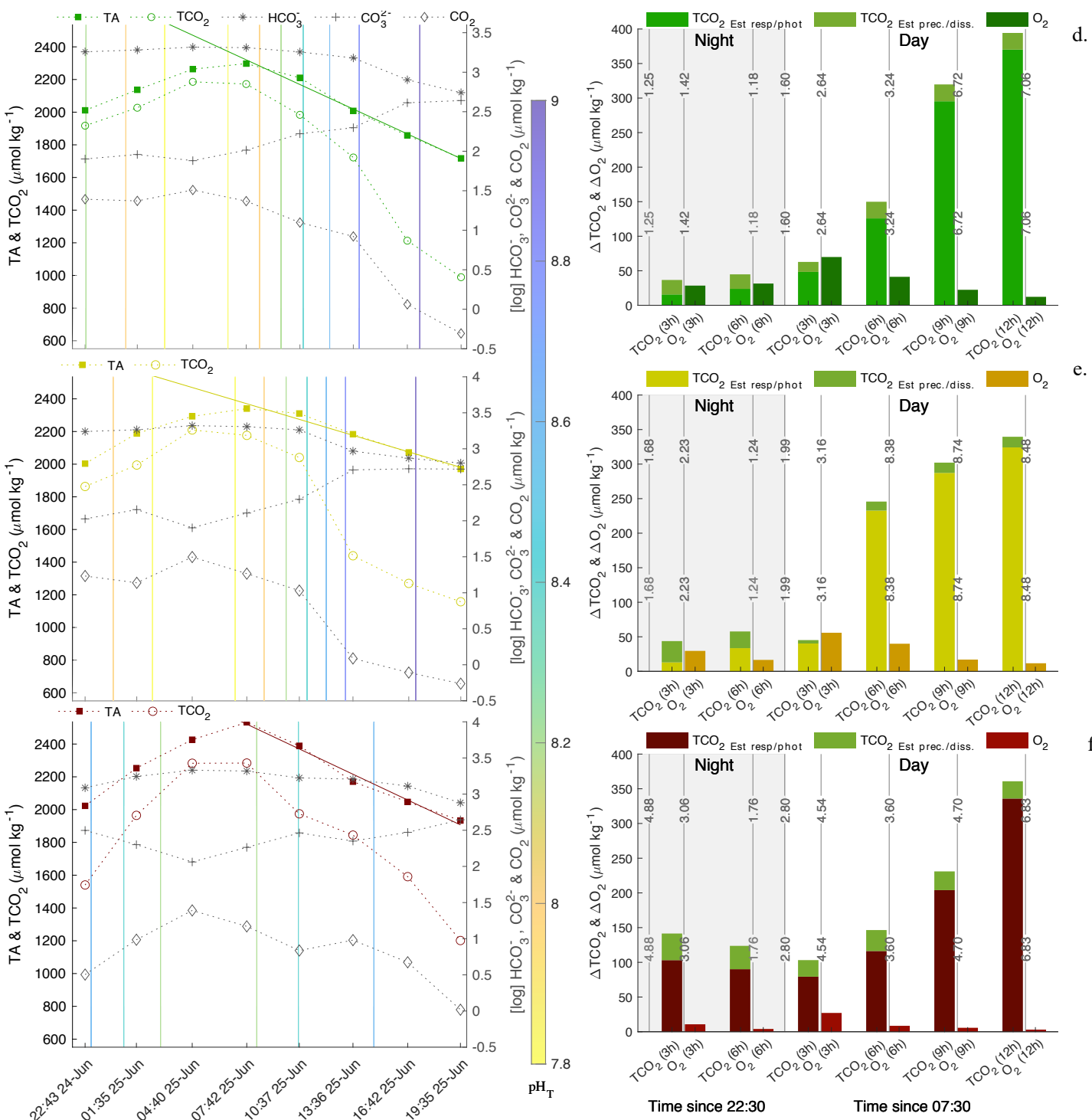

Figure 2. Alkalinity and $\mathrm{TCO}_{2}$ (left y-axis) during $21 \mathrm{~h}$ emersion sampling period for dense grass (a), patchy grass (b), and no grass (c) pools. The log concentration of $\mathrm{CO}_{2}$, $\mathrm{HCO}_{3}{ }^{-}$, and $\mathrm{CO}_{3}{ }^{2-}$ are marked as grey on the right $\mathrm{y}$-axis with colored $\mathrm{pH}_{\mathrm{T}}$ isoclines. Absolute values of $\Delta \mathrm{TCO}_{2}$ and $\Delta \mathrm{O}_{2}$ during same emersion period where the total $\triangle \mathrm{TCO}_{2}$ was estimated based on proportion of change due to biological respiration/photosynthesis or $\mathrm{CaCO}_{3}$ precipitation/dissolution for dense grass (d), patchy grass (e), and no grass (f).

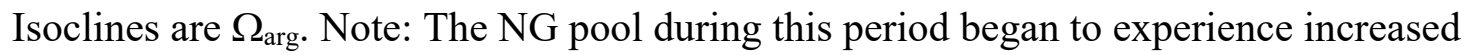
salinity due to evaporation reducing confidence in the displayed values. 
605

606

607

608

609

610

611

612

613

614

615

616

617

618

619

620

621

622

14

15

16

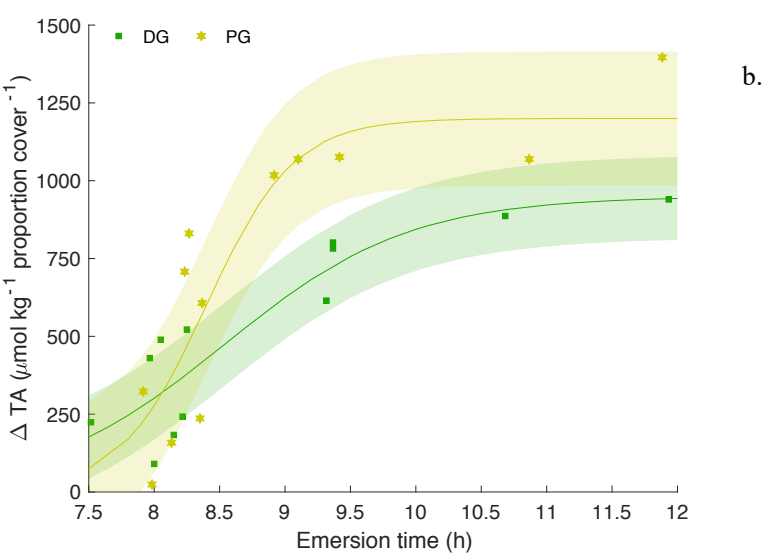

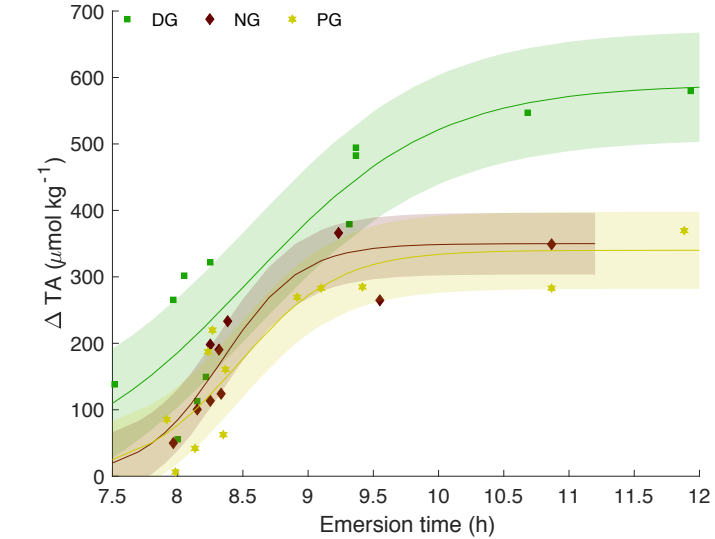

Figure 3. The $\Delta \mathrm{TA}$ and $\Delta \mathrm{TA}$ per proportion of seagrass cover as a function of emersion time for dense grass (DG) and patchy grass (PG) in panels (a) and (b), and no grass (NG) pool in panel (a). Highlighted region is the RMSE of modeled logistical fit.

13

.


b.
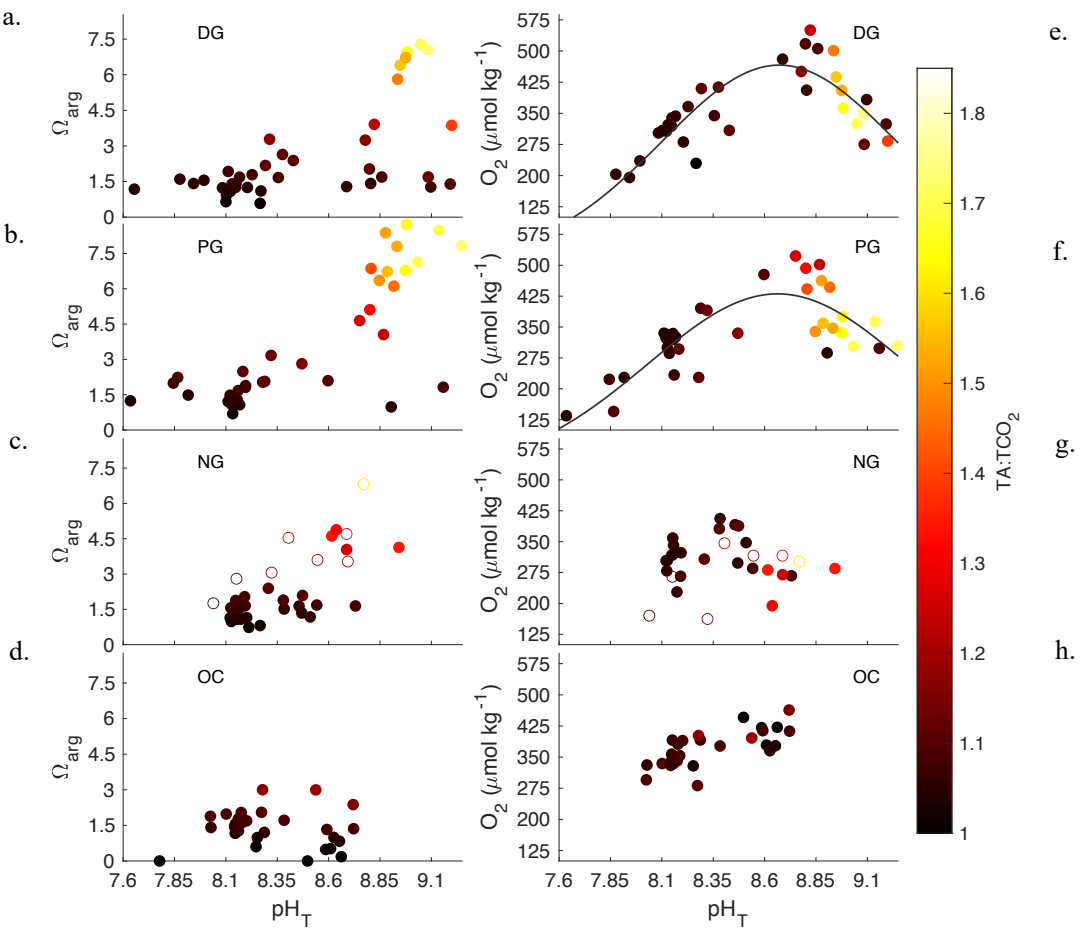

d.
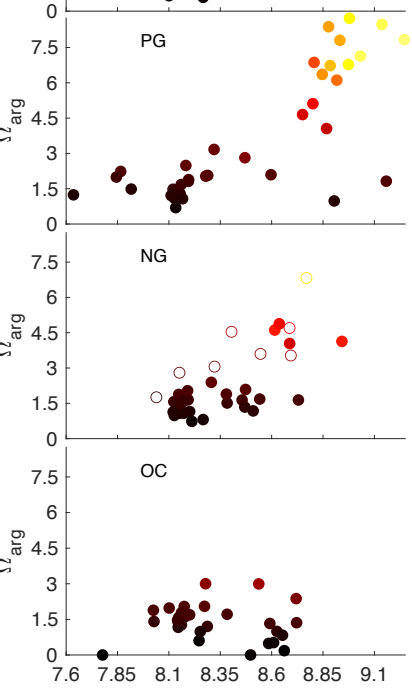

$\mathrm{pH}_{\mathrm{T}}$

Figure 4. All sample points of $\Omega_{\mathrm{arg}}(\mathbf{a}-\mathbf{d})$ and $\mathrm{O}_{2}$ concentration $(\mathbf{e}-\mathbf{h})$ correlated to $\mathrm{pH}_{\mathrm{T}}$ for

626 dense grass (DG), patchy grass (PG), no grass (NG), and ocean (OC). Color bar is the

627 measured TA: $\mathrm{TCO}_{2}$ ratio for each point in the timeseries. Gaussian fits applied to DG

628 pool with an RMSE of 51.39 and 55.68 for the PG pool. Open circles in panels (c) and

629 (g) indicate measurements taken after 24 June during NG pool evaporation.

630

631

632

633

634

635

636

637

638

639

640

641

642 

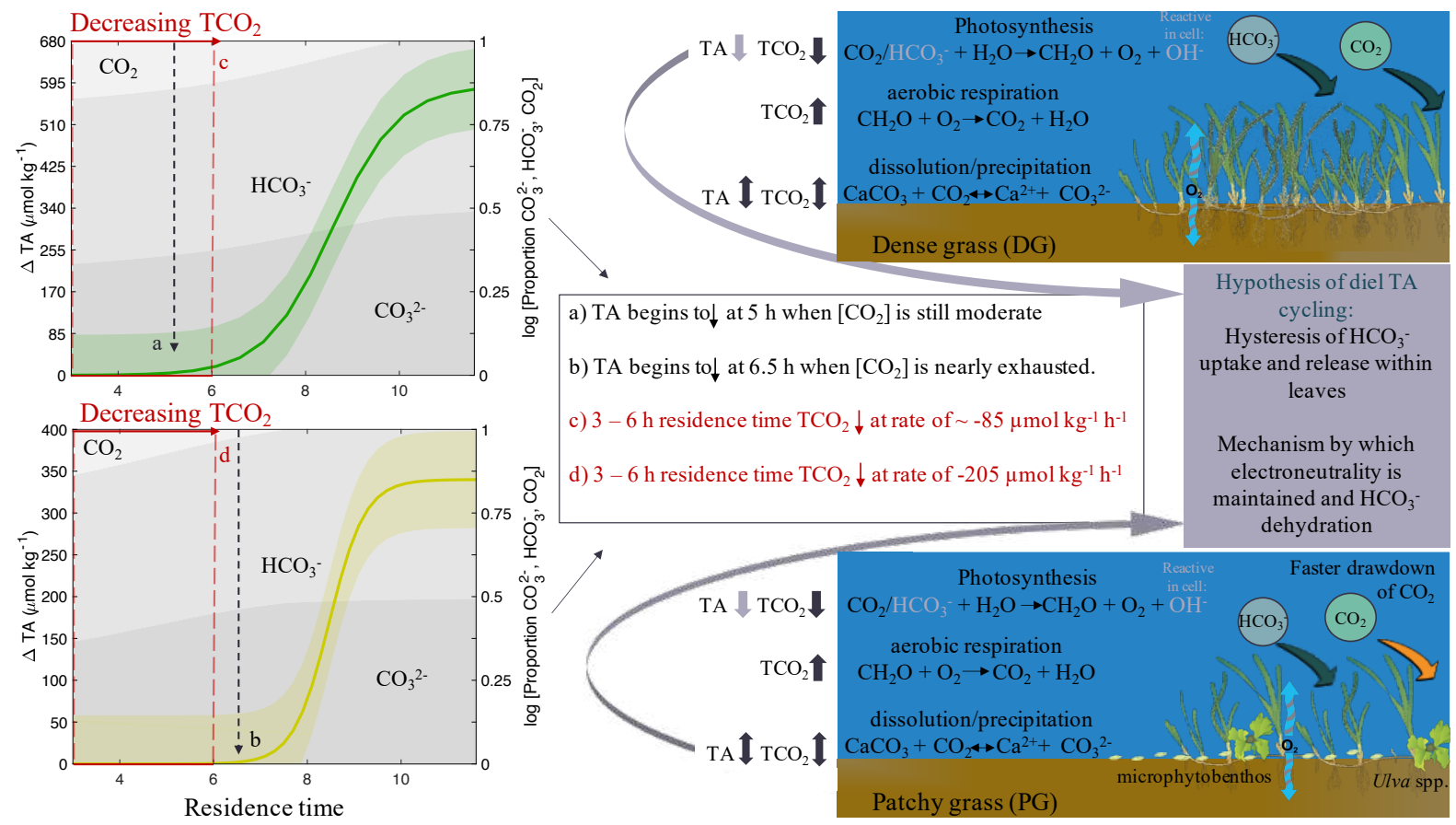

644 Figure 5. Conceptual model plots of $\Delta T A$ as a function of residence time and the

645 concomitant change in carbonate chemistry speciation (shaded in grey) for dense grass

646 (green) and patchy grass (yellow) based on measurements presented in Figs. 3 and 4.

647 Dashed lines on plots indicate specific time points at which TA decreases, rate of $\Delta \mathrm{TCO}_{2}$,

648 and carbonate chemistry speciation. Potential processes modulating TA are depicted in

649 stoichiometric equations with hypothesized processes modulating TA based on this study

650 shown with purple arrows and text box. 
Figures

a.

b.

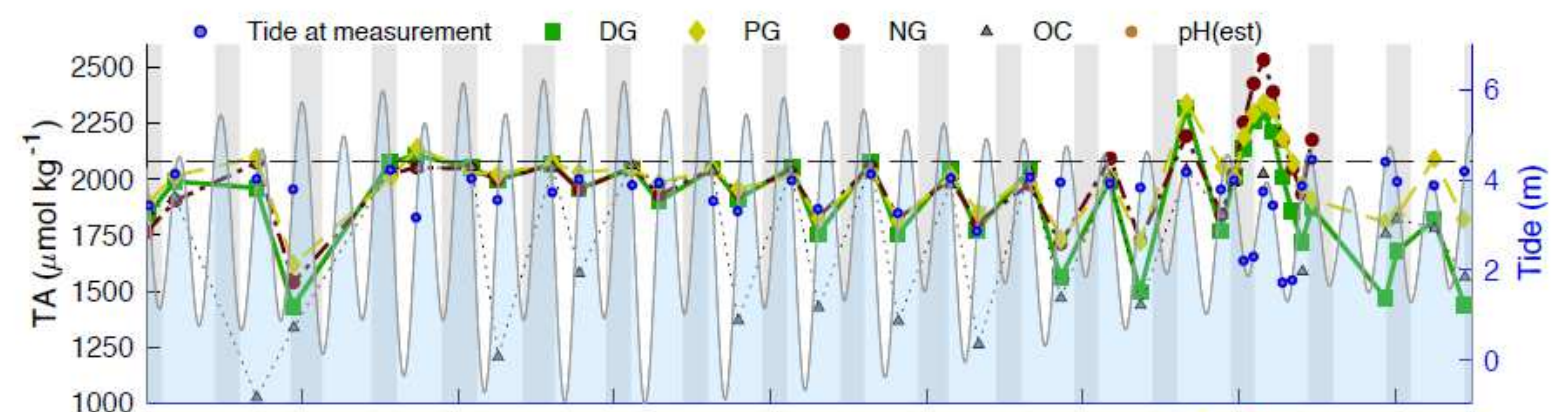

c.
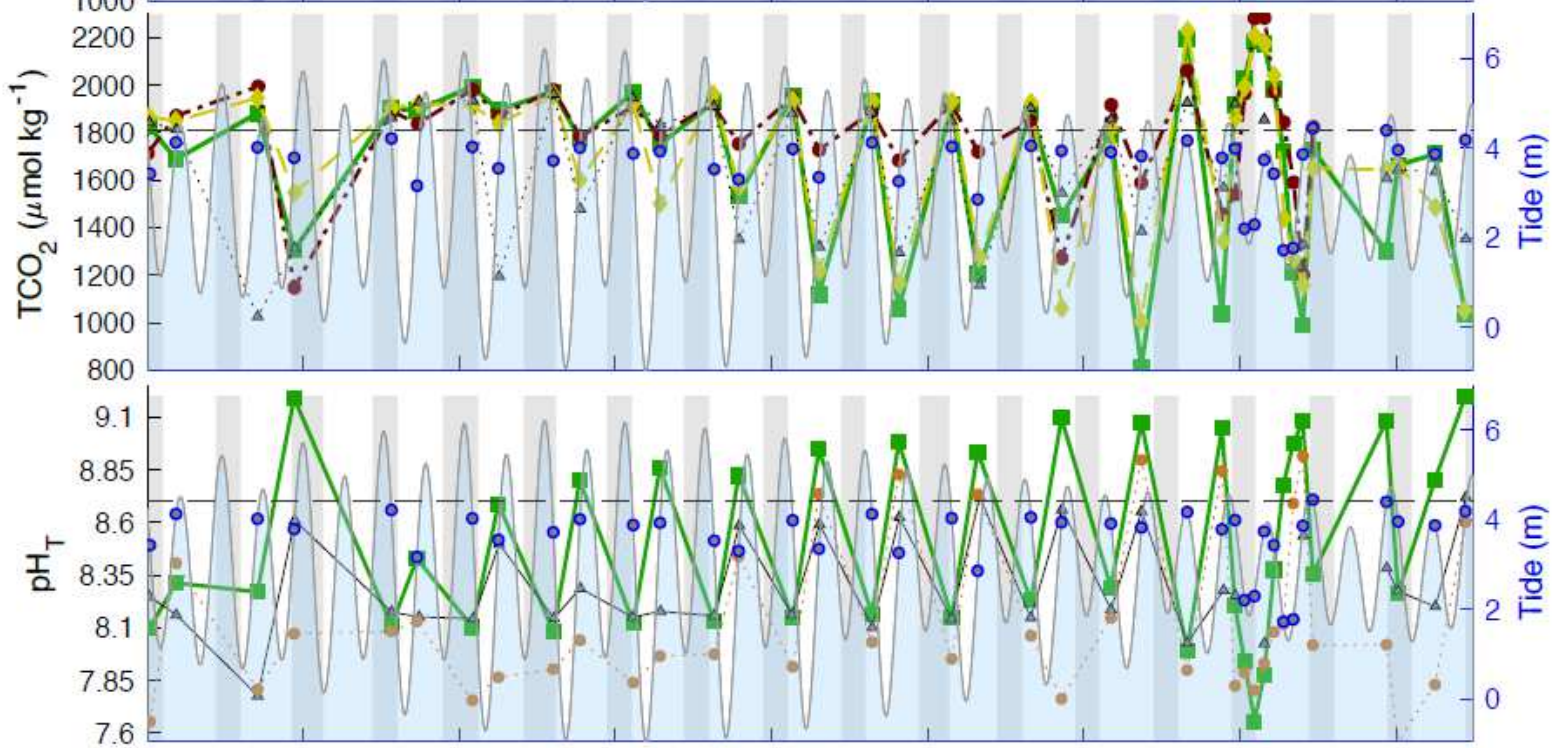

d.

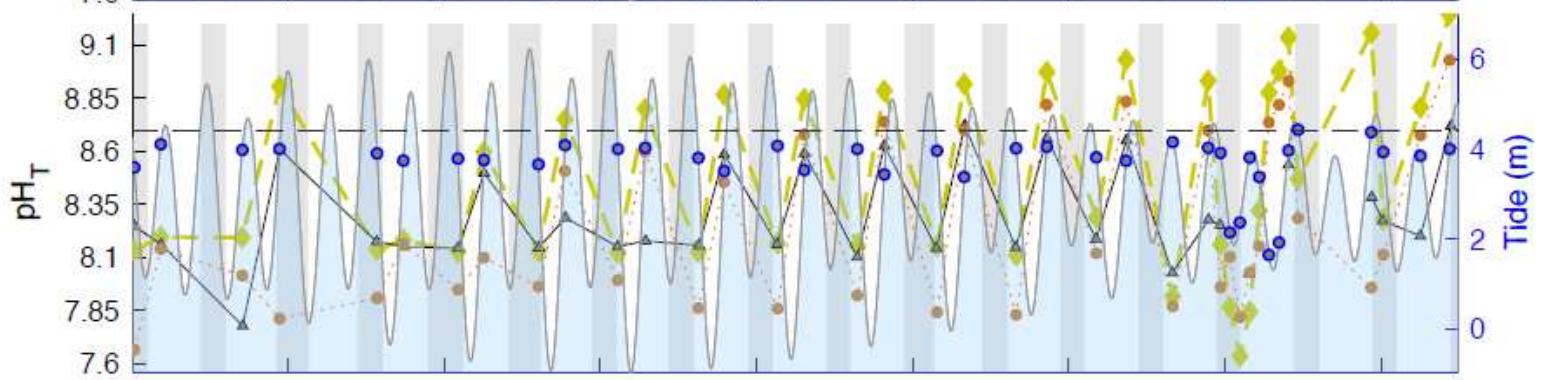

e.

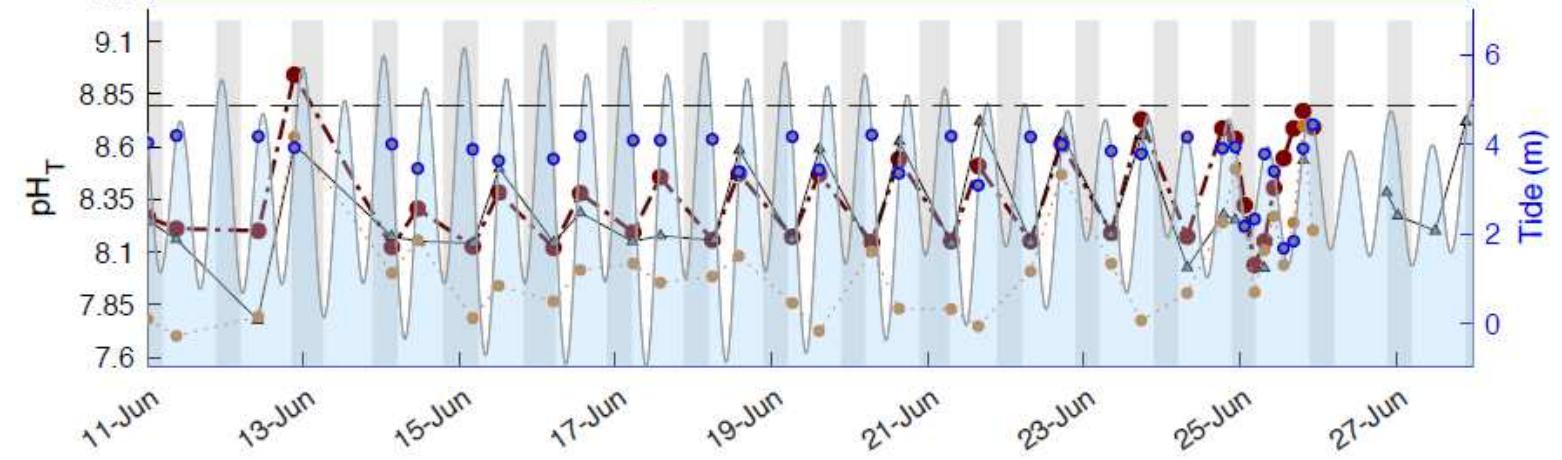

\section{Figure 1}

Timeseries of measured TA (a), TCO2 (b), pHT and estimated pHT (c-e) in dense grass (DG), patchy grass $(P G)$, no grass (NG), and ocean (OC). Shaded blue region is predicted tide and shaded grey is night when PAR $<100 \mu$ mol photons $\mathrm{m}-2 \mathrm{~s}-1$. Dashed line indicates tidal height when pools become immersed and 
tidal height at when samples were taken (blue dots). Three-hour sampling occurred for a period of $24 \mathrm{~h}$ starting 24 June 22:30.

a.

b.
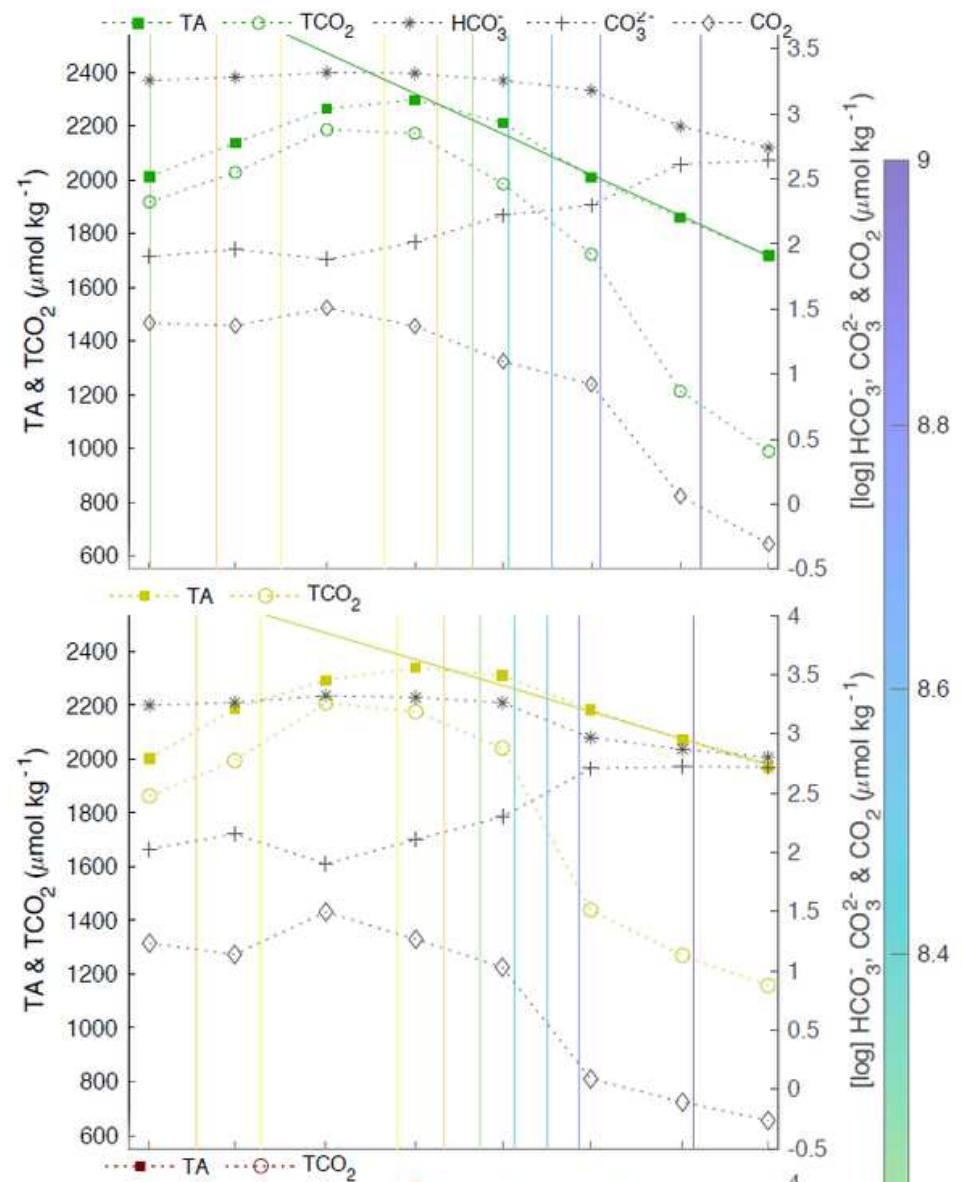

c.

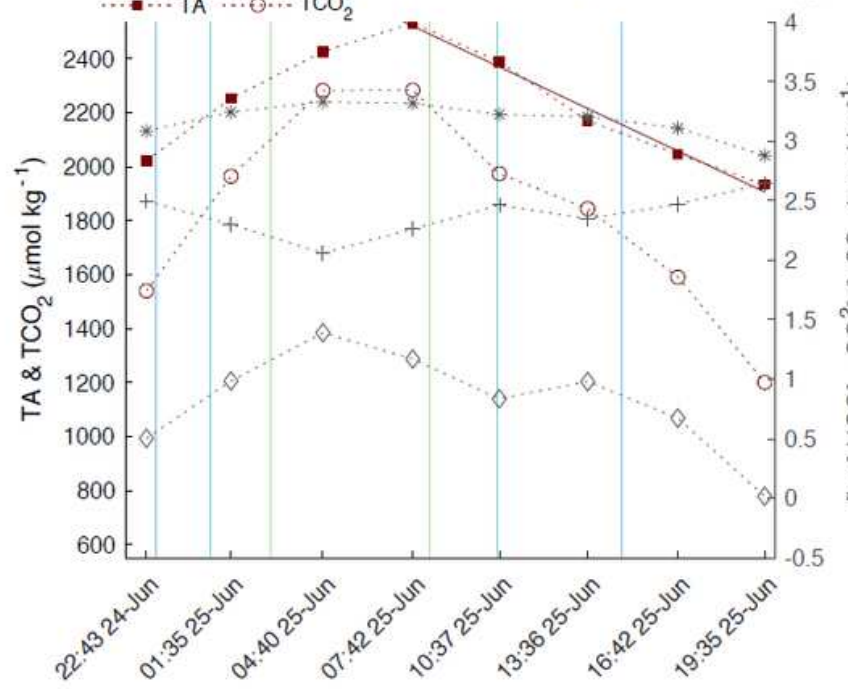

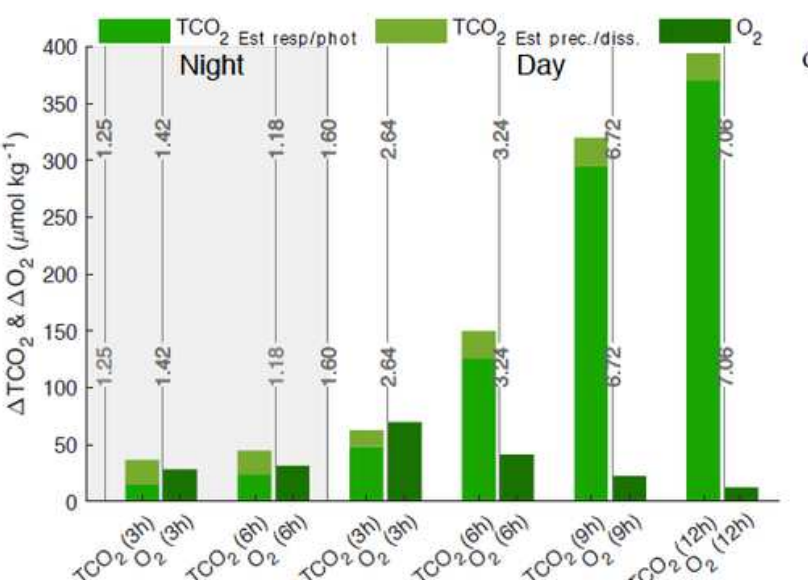
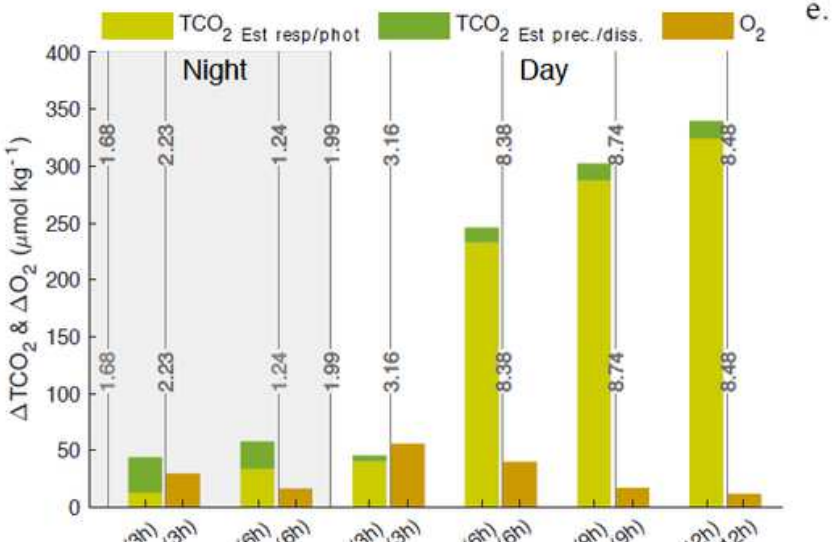

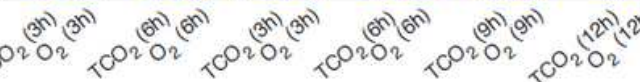

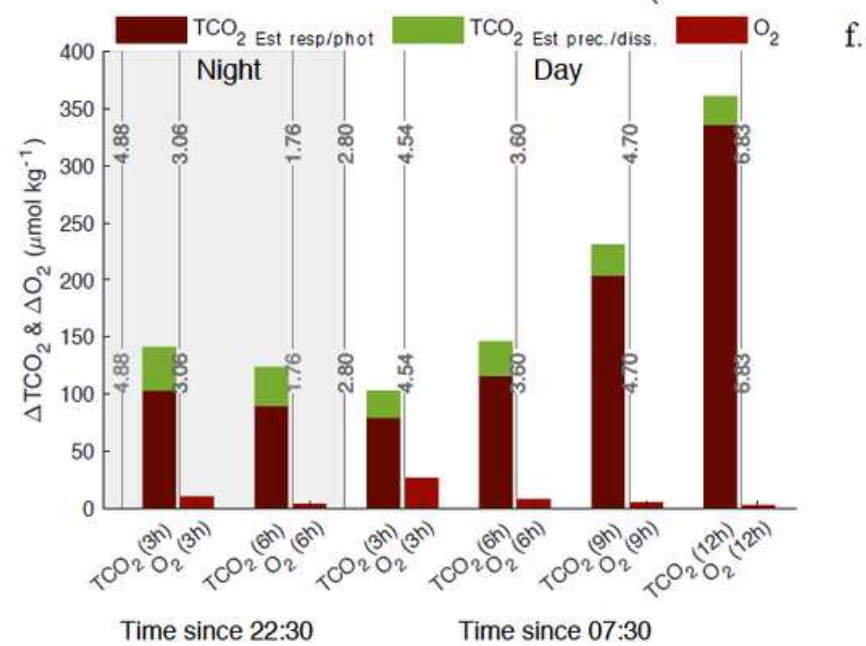

\section{Figure 2}

Alkalinity and TCO2 (left y-axis) during $21 \mathrm{~h}$ emersion sampling period for dense grass (a), patchy grass (b), and no grass (c) pools. The log concentration of $\mathrm{CO} 2, \mathrm{HCO} 3$-, and $\mathrm{CO} 32$ - are marked as grey on the right $\mathrm{y}$-axis with colored $\mathrm{pHT}$ isoclines. Absolute values of $\triangle \mathrm{TCO} 2$ and $\triangle \mathrm{O} 2$ during same emersion period where the total $\triangle \mathrm{TCO} 2$ was estimated based on proportion of change due to biological respiration/photosynthesis or $\mathrm{CaCO} 3$ precipitation/dissolution for dense grass (d), patchy grass (e), and 
no grass (f). Isoclines are $\Omega$ arg. Note: The NG pool during this period began to experience increased salinity due to evaporation reducing confidence in the displayed values.

a.

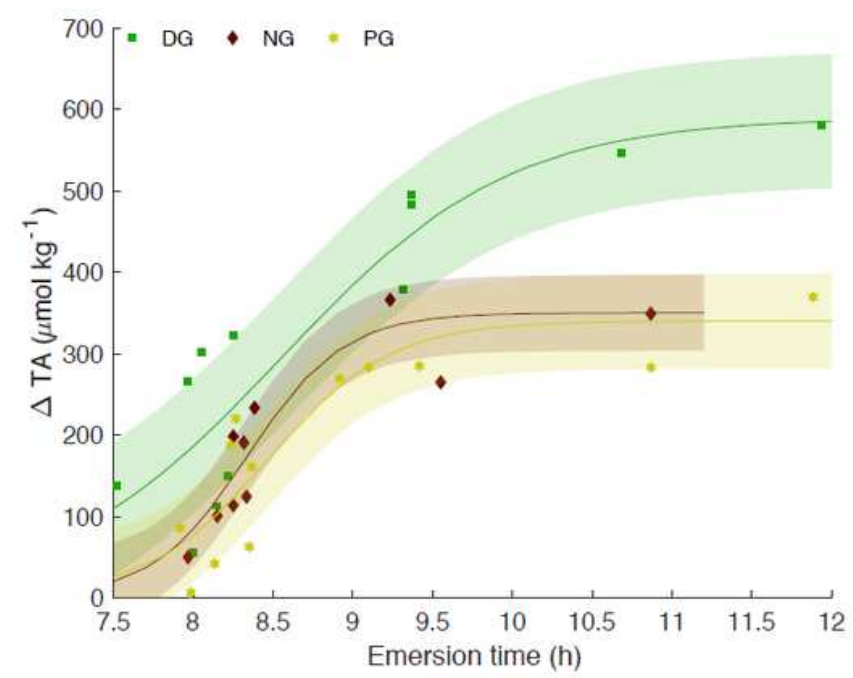

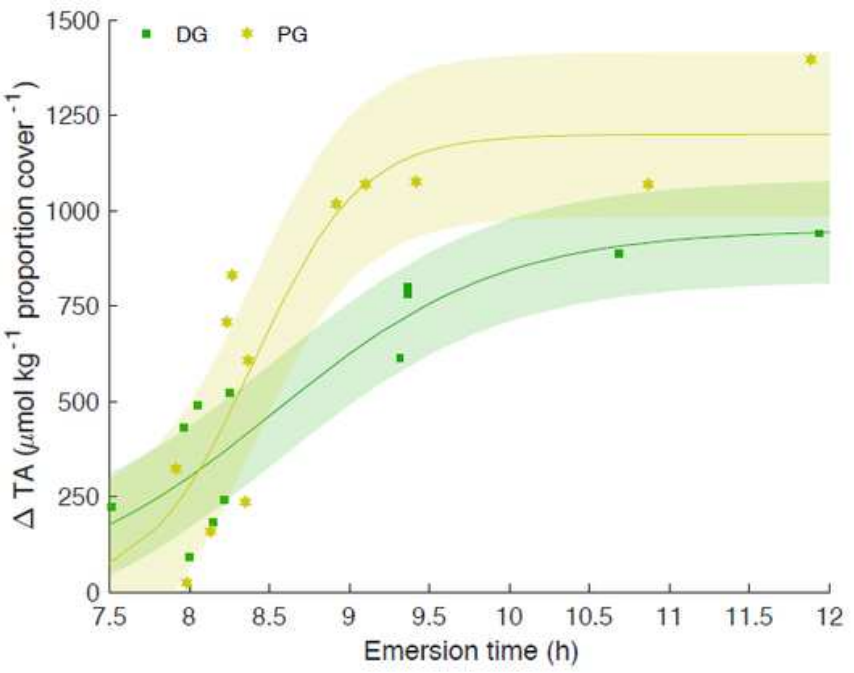

b.

\section{Figure 3}

The $\triangle T A$ and $\triangle T A$ per proportion of seagrass cover as a function of emersion time for dense grass (DG) and patchy grass (PG) in panels (a) and (b), and no grass (NG) pool in panel (a). Highlighted region is the RMSE of modeled logistical fit. 



e.

f.

g.

h.

Figure 4

All sample points of $\Omega$ arg (a-d) and 02 concentration (e-h) correlated to pHT for dense grass (DG), patchy grass (PG), no grass (NG), and ocean (OC). Color bar is the measured TA:TCO2 ratio for each point in the timeseries. Gaussian fits applied to DG pool with an RMSE of 51.39 and 55.68 for the PG pool. Open circles in panels (c) and (g) indicate measurements taken after 24 June during NG pool evaporation. 

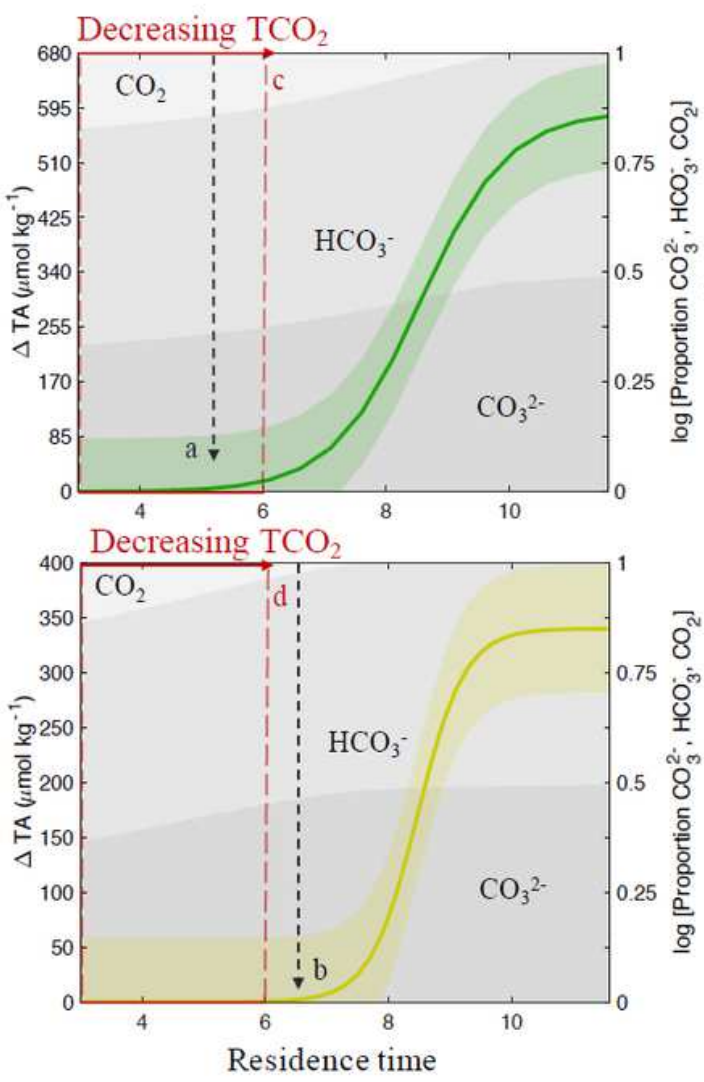

a) TA begins to $\downarrow$ at $5 \mathrm{~h}$ when $\left[\mathrm{CO}_{2}\right]$ is still moderate

b) TA begins to $\downarrow$ at $6.5 \mathrm{~h}$ when $\left[\mathrm{CO}_{2}\right]$ is nearly exhausted.

c) $3-6 \mathrm{~h}$ residence time $\mathrm{TCO}_{2} \downarrow$ at rate of $\sim-85 \mu \mathrm{mol} \mathrm{kg}-1 \mathrm{~h}^{-1}$

d) $3-6 \mathrm{~h}$ residence time $\mathrm{TCO}_{2} \downarrow$ at rate of $-205 \mu \mathrm{mol} \mathrm{kg} \mathrm{g}^{-1} \mathrm{~h}^{-1}$

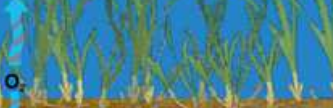

(1)

Hypothesis of diel TA cycling:

Hysteresis of $\mathrm{HCO}_{3}$ uptake and release within leaves

Mechanism by which electroneutrality is maintained and $\mathrm{HCO}_{3}$ dehydration

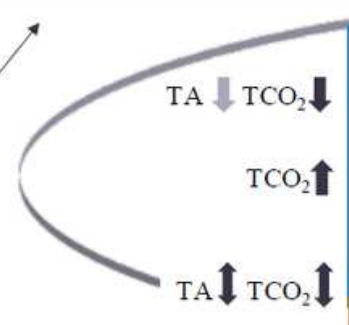
Faster drawdown

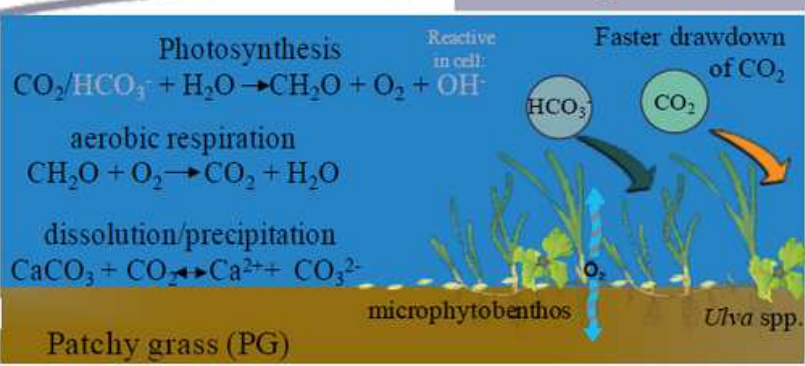

\section{Figure 5}

Conceptual model plots of $\triangle T A$ as a function of residence time and the concomitant change in carbonate chemistry speciation (shaded in grey) for dense grass (green) and patchy grass (yellow) based on measurements presented in Figs. 3 and 4. Dashed lines on plots indicate specific time points at which TA decreases, rate of $\triangle \mathrm{TCO} 2$, and carbonate chemistry speciation. Potential processes modulating TA are depicted in stoichiometric equations with hypothesized processes modulating TA based on this study shown with purple arrows and text box.

\section{Supplementary Files}

This is a list of supplementary files associated with this preprint. Click to download.

- SupplementaryInformationAppendix.pdf 